\section{Pacific Northwest}

National Laboratory

Operated by Battelle for the

U.S. Department of Energy

\title{
2001 Columbia River Recreation Survey- Implications for the Hanford Site Integrated Assessment
}

\author{
D.M. Anderson \\ M.J. Scott \\ A.L Bunn \\ R.A. Fowler \\ E.L. Prendergast \\ T.B. Miley \\ T.O. Eschbach \\ J.A. Jaksch
}

March 2002

Prepared for the U.S. Department of Energy under Contract DE-AC06-76RL01830 


\section{Columbia River Recreation Survey-Implications for the Hanford Site Integrated Assessment}

D. M. Anderson

M. J. Scott
A. L. Bunn
R. A. Fowler
E. L. Prendergast
T. B. Miley
T. O. Eschbach
J. A. Jaksch

March 2002

Prepared for

the U.S. Department of Energy

under Contract DE-AC06-76RL01830

Pacific Northwest National Laboratory

Richland, Washington 99352 


\section{Summary}

This report presents the results from the 2001 Columbia River Recreation Survey conducted in the summer of 2001. That survey combined on-site personal interviews of parties engaged in river recreation with on-site field observations to develop a picture of summer river recreation on the Columbia. The study area extended from just below Priest Rapids Dam in the north to McNary Dam in the south. It was divided into four areas that correspond to the river areas used by the Groundwater/Vadose Zone Integration Project. This study was commissioned as part of that on-going larger integrated assessment.

This study was commissioned specifically to document the current recreation use levels in these areas of the river, and to elicit information on recreation-related expenditure from visitors. Economic and environmental models use this information to measure the economic and environmental risk posed by possible, but unlikely, releases of contaminants from the Hanford Site into the Columbia River.

During the study period, researchers collected 256 survey responses and 396 field observations from recreation sites up and down both shores of the river in the study area. Results presented include analysis of trip duration by river activity, trip frequency, and visitor place of origin. Economics-related results include trip expenditure profiles defined by activity and place of origin. In addition, data on fishing efforts were collected. Visitors also were asked to indicate what substitute activity or destination they would choose instead in a hypothetical example where the river could not be accessed.

Key findings include the following:

- The average summer river visitor spends more than $\$ 32$ per river trip, of which about $\$ 18$ is spent in the local economy. These numbers vary widely based on the activity set of the visitor. Boaters and water-skiers spend much more per person, while sightseers and swimmers spend much less.

- The average summer river recreation party consists of three adults and two children.

- Summer river recreationists take an average of more than 47 trips to the river each year.

- Summer visitors spend an average of 5.6 hours on a trip to the river. This time is composed of 1.5 hours of swimming, 0.9 hours of boating, 0.8 hours of water skiing, 0.7 hours of fishing, and 1.6 hours of other activities, including picnicking, walking, and sightseeing.

The report also highlights some limitations in the approach. Principally, because the field research occurred only during the summer, recreational use of the river in the other seasons was not documented. The report provides other data that suggest considerable activity of the other seasons - particularly spring and fall - for salmon and steelhead fishing. This stretch of the Columbia is also well known for waterfowl hunting.

Appendixes provide the actual data collection tools, a characterization of the environmental and economic modeling requirements, and statistical tables of use in model calibration. 



\section{Acknowledgments}

The authors would like to publicly thank the following individuals for their efforts in facilitating data collection and for their ultimate contributions to this report:

- Consultation on survey design: K.M. Branch, R.L. Conger, R.R. Uptmor, T.M. Poston, and R.L. Dirkes

- Human subjects research protocol: S.E. Davis

- Health and safety plan: P.A. Wright

- Data collection training: D.K. Tano, J.M. Becker, S.E. Davis and A.C. Rither

- Data collection team: K. Brown, M. Hoertkorn, D. Hughes, J. Kirk, J. Koppenaal, J. Marples, F. Melendez, R. Parkhill, E. Schweighardt, N. Smith, and K. Trujillo

- Data entry: F. Melendez, R. Parkhill and K. Trujillo 



\title{
Acronyms/Abbreviations
}

\author{
Corps U.S. Army Corps of Engineers \\ DOE U.S. Department of Energy \\ IRB Institutional Review Board \\ n Sample Size \\ NA Not applicable \\ PNNL Pacific Northwest National Laboratory \\ RVD recreation visitor days \\ SAC Groundwater/Vadose Zone Integration Project System Assessment Capability \\ SD Standard Deviation \\ TCERM Tri-Cities Economic Risk Model \\ WDFW Washington State Department of Fish and Wildlife
}





\section{Contents}

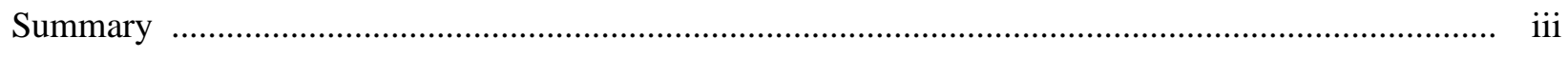

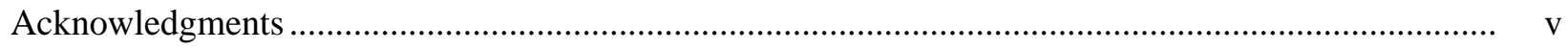

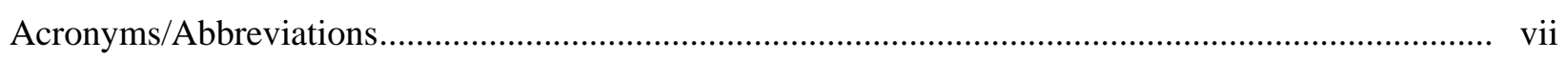

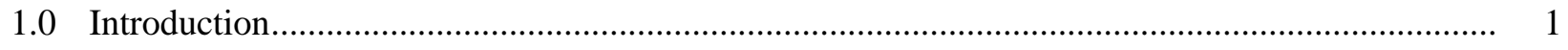

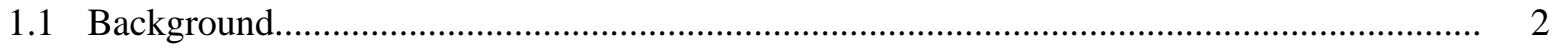

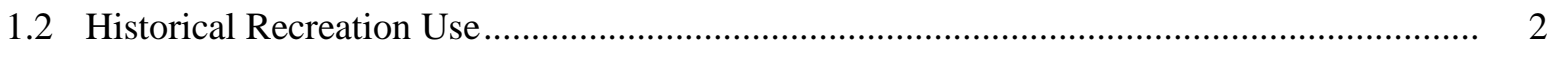

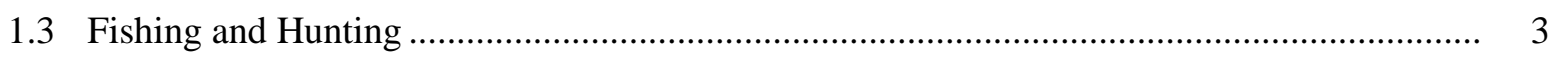

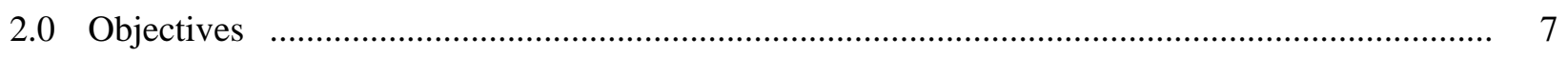

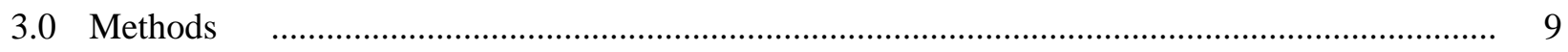

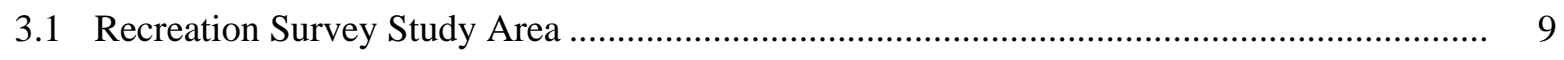

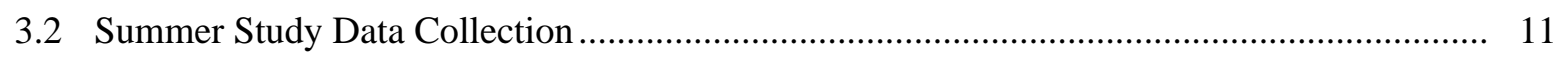

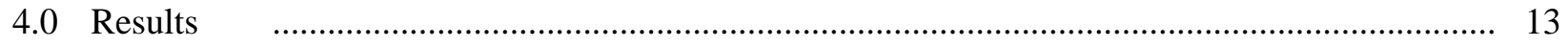

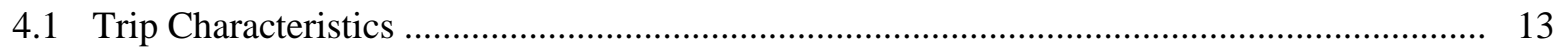

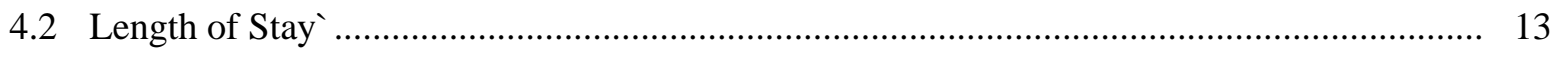

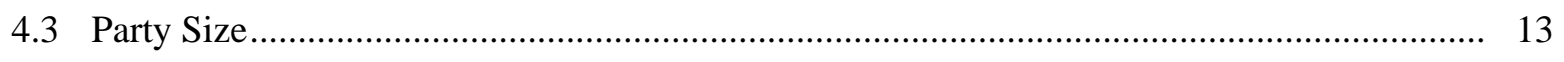

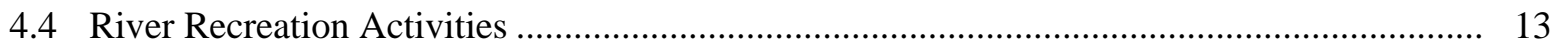

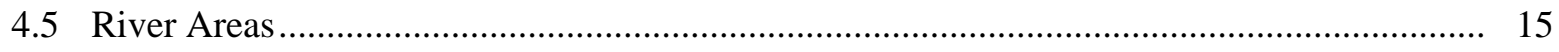

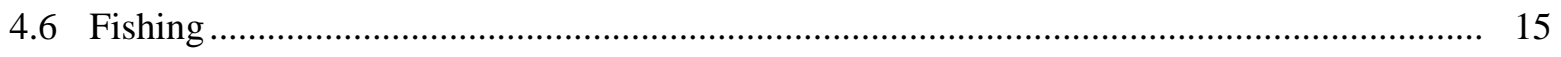

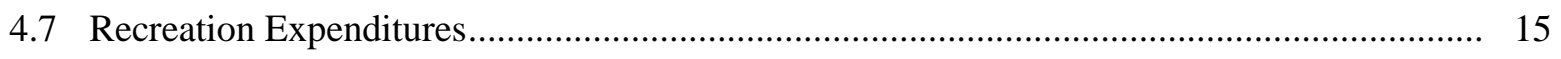

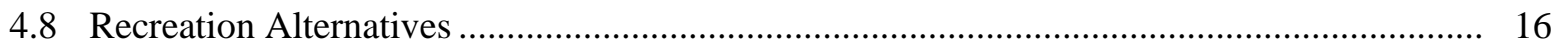

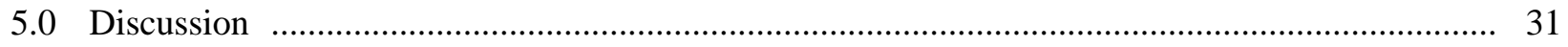

6.0 References 


\section{Figures}

3.1 Groundwater/Vadose Zone Integration Project Study Area with the Regions for the 2001 Columbia River Recreation Survey

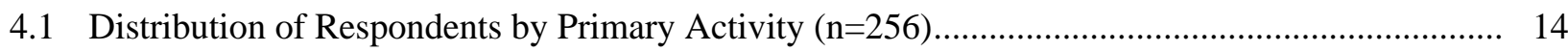




\section{Tables}

1.1. 1994-1999 Recreation Visits to Lake Wallula Sites (USACE 2001) ........................................... 4

1.2 Summary of Boat Angling Effort in the Hanford Reach .................................................. 5

1.3 2001-2001 Summary of Bank Angling Effort in the Hanford Reach ....................................... 5

1.4 WDFW Northern Pikeminnow Sport-Reward Fishery Program Summary ................................. 6

3.1 Data Collection Effort by River Area during Summer 2001 Study Period................................. 12

3.2 Data Collection Effort by County during Summer 2001 Study Period .................................... 12

4.1 Visitor Origin and Party Size Characteristics ................................................................. 16

4.2 Visitor Origin and Party Size Characteristics for Study Area Residents .................................... 16

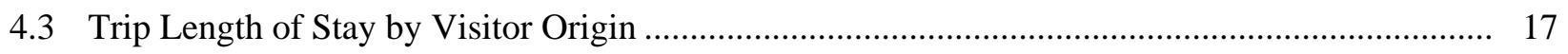

4.4 River Recreation Visits per Year by Respondent Origin ................................................... 17

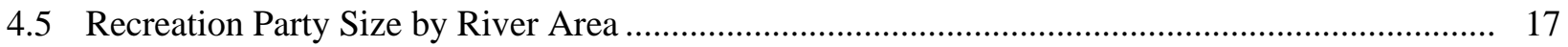

4.6 Recreation Activity Duration by Primary Activity …........................................................ 18

4.7 Composite Trip Activity Duration (Hours/Trip) by River Area ............................................ 18

4.8 Boating Trip Activity Duration (Hours/Trip) by River Area.................................................... 19

4.9 Swimming Trip Activity Duration (Hours/Trip) by River Area ............................................... 19

4.10 Bank Fishing Trip Activity Duration (Hours/Trip) by River Area ............................................ 19

4.11 Boat Fishing Trip Activity Duration (Hours/Trip) by River Area .......................................... 20

4.12 Waterskiing Trip Activity Duration (Hours/Trip) by River Area ........................................... 20

4.13 Other Activities Trip Activity Duration (Hours/Trip) by River Area......................................... 20

4.14 Picnicking Trip Activity Duration (Hours/Trip) by River Area .............................................. 21

4.15 Water Follies Trip Activity Duration (Hours/Trip) by River Area........................................ 21

4.16 Walking/Hiking Trip Activity Duration (Hours/Trip) by River Area ...................................... 21 
4.17 Sightseeing/Observation Trip Activity Duration (Hours/Trip) by River Area

4.18 "No Specified Activity” Trip Activity Duration (Hours/Trip) by River Area.

4.19 Study Area Average Counts of Recreation Activity Participation by Weekday 23

4.20 Average Counts of Recreation Activity Participation by Weekday in Area 1

4.21 Average Counts of Recreation Activity Participation by Weekday in Area 2

4.22 Average Counts of Recreation Activity Participation by Weekday in Area 3 24

4.23 Proportion of Trip Time by River Area 24

4.24 Target Species of Fishing Parties. 25

4.25 Total and Local Portion Trip Expenditure Profile for Entire Sample ( $n=219$ parties) 25

4.26 River-Based Recreation Trip Expenditures (Dollars) by Party by Activity 26

4.27 River-Based Recreation Trip Expenditures (Dollars) by Part by Point of Origin 28

4.28 River-Based Recreation Trip Expenditures (Dollars) by Party by River Area 29 


\subsection{Introduction}

From its creation in 1943 until recently, Hanford Site facilities were dedicated primarily to the production of weapons-grade plutonium for national defense. The current missions of the Hanford Site are to safely clean up and manage Site legacy wastes, and to develop and deploy science and technology. Although many important milestones have been accomplished that support the Hanford Site strategic goals, the cleanup mission is complex and the potential exists for fundamental gaps, overlaps, and inefficiencies to occur among the multiple projects. Federal and state regulators, stakeholders, and Tribal Nations have voiced concerns over the real and perceived threats that Hanford Site contaminants pose to the aquifer underlying the Hanford Site and to the Columbia River (DOE 1998; DNFSB 94-2).

Responding to these concerns in late 1997, the DOE established the Groundwater/Vadose Zone Integration Project. The Project was to be a catalyst for fundamental change at the Site. One dimension of that change was the creation and application of a cumulative impact assessment for Hanford Site wastes on the subsurface environment and on the Columbia River. Through the application of the assessment capability, decisions for each cleanup and disposal action will determine the composite effect of other cleanup and disposal actions.

The System Assessment Capability (SAC) of the Groundwater/Vadose Zone Integration Project is an evolving and maturing capability to assess the cumulative impacts of radioactive and chemical waste at the Hanford Site. This capability will assess Hanford Site impacts on water resources, living systems, cultures, and regional economics. A key element of the system being assessed is the Columbia River. The results of this assessment allow site-specific cleanup decisions and disposal authorizations to be based on the overall impact of Hanford on the region. The assessment also provides useful information for making Site operational decisions, such as cleanup prioritization, funding allocation, and determination of additional data needs. In the long term, the SAC will provide important information to Site closure decisions; include a quantification of uncertainty, and a broad suite of quantitative and qualitative risk and impact metrics. The initial SAC is posed as an analysis of human and ecological health, as well as the cultural and socioeconomic impacts.

Recreational use of the Columbia River is a key component of the risk and impacts of the SAC. Future perception of environmental risk in the river, valid or not, could affect the amount and type of recreation activity and the level of associated spending in the local economy. However, the importance of such changes has not yet been calculated. Recreation is considered in the human health assessment (as assessed by the HUMAN code) and the economic impact predictions, as assessed by the TCERM code (see Appendix A). Parameters for recreational activity needed for these analyses include:

- Level and duration of water-based activities in the Columbia River between Priest Rapids Dam and McNary Dam, such as swimming, boating, fishing, and hunting. This information is needed for the health effects and economic studies, however, the health effects studies may dispense with this information if they are conducted primarily with "worst case" conservative exposure scenarios. 
- Spending in the Tri-Cities economy related to these activities. This information is needed only by the economics studies.

- Changes in the level and mix of these activities on the Columbia River are not available. This information can be useful to the health studies, but is primarily used by the economics studies.

Discussion of these issues is available in a recent study (Kincaid et al. 2000). In addition, understanding recreation use is important to any plans for the Columbia River corridor bordering the Hanford Site and the Hanford Reach National Monument. The purpose of the study is to establish a current baseline of recreation use and value on the Columbia River in the Tri-Cities vicinity for use in estimating health and economic impact. The proposed study area is from Priest Rapids Dam downstream to McNary Dam, approximately 100 miles, and upstream into the Snake River, a distance of two miles. To date, few studies have documented the use of the Columbia River in the proposed study area. This project will conduct a survey of the recreational locations throughout the study area and provide a basis for the parameters in the risk and impact modules for the SAC.

\subsection{Background}

One principal component of the Integration Project SAC approach includes identifying and measuring the economic characteristics of direct human use of the Columbia River. Direct human uses of the river include such recreational activities as boating, swimming/wading, fishing, and water-skiing where contact with the water is the basis for the activity. Indirect human uses might include irrigated agriculture, drinking water supply, and river transportation, but direct contact with untreated river water is not likely.

This study reports results associated with the direct recreational use of the river. It provides estimates of the levels of human recreational use over the stretch the river from the Lake Wallula pool to the upper portion of the Hanford Reach - just below Priest Rapids Dam. It further provides characterization of particular recreational activities engaged in by participants and associated activity expenditure profiles.

\subsection{Historical Recreation Use}

The Corps manages the McNary Project and reports annual recreation use statistics for most major developed recreation sites touched by Lake Wallula. Lake Wallula touches Integration Project river Areas 3 and 4. The Corps provides a consistent series of use data for the 1994-1999 period for all developed parks on Lake Wallula (USACE 2001). Table 1.1 summarizes those data.

The Corps recreation use data show declining to flat levels of use at Lake Wallula facilities over the 1994-1999 period, with notable exceptions. Population growth in the Tri-Cities since 1994 has been significant, indicating that river recreation in Area 3 would have increased correspondingly. However, widespread new riverfront development during that time, particularly in Richland, accounts for reductions in park visits. Columbia Park and Chiawana Park do show significant growth in visitation for that period - corresponding to annual population growth. 
These visitor statistics provide only annual estimates of visits to the parks of the region. Such estimates typically are based on automated car counts multiplied by an average persons-per-vehicle factor. Further, they do not attempt to measure specific recreation activities.

\subsection{Fishing and Hunting}

The Columbia River and its bordering marshland and wetlands in the study area are well known prime fishing and waterfowl hunting areas. Spring and Fall Chinook runs, Summer and Winter Steelhead runs, and many other game fish make the study area very popular with anglers from around the Mid Columbia and the Northwest. The location of the region on the Pacific Flyway for migratory waterfowl also provides outstanding duck and goose hunting in the fall. Though outside the data collection window for this study, these uses of the river are summarized by referencing data maintained by the State of Washington for monitoring harvest and harvest effort. Tables 1.2 and 1.3 illustrate a portion of the fishing effort as measured by the Washington State Department of Fish and Wildlife (WDFW 2002). Table 1.3 provides a summary of the Northern Pikeminnow reward season (WDFW 2002). These data represent only samples of fishing use and do not reflect total fishing effort or catch. 
Table 1.1. 1994-1999 Recreation Visits to Lake Wallula Sites (USACE 2001)

\begin{tabular}{|c|c|c|c|c|c|c|c|c|}
\hline Site Name & Area & 1994 & 1995 & 1996 & 1997 & 1998 & 1999 & $\begin{array}{c}\text { Annual } \\
\text { Change } \\
(\%)\end{array}$ \\
\hline Columbia Park & 3 & 911,451 & $1,264,200$ & $1,147,735$ & $1,094,800$ & $1,148,300$ & $1,272,000$ & 5.7 \\
\hline $\begin{array}{l}\text { Howard Amon } \\
\text { Park }\end{array}$ & 3 & $1,531,800$ & 986,900 & 775,800 & 810,600 & 820,500 & 890,800 & -6.0 \\
\hline Leslie Groves Park & 3 & 901,759 & 747,100 & 764,573 & 785,900 & 620,200 & 625,900 & -4.4 \\
\hline Chiawana Park & 3 & 119,030 & 123,300 & 191,289 & 167,500 & 151,500 & 226,200 & 12.9 \\
\hline Two Rivers Park & 3 & 134,691 & 157,700 & 201,773 & 143,800 & 172,500 & 162,000 & 2.9 \\
\hline $\begin{array}{l}\text { Pasco Boat Basin } \\
\text { (Schlagel Park) }\end{array}$ & 3 & 72,615 & 79,000 & 86,049 & 81,600 & 94,500 & 90,000 & 3.4 \\
\hline $\begin{array}{l}\text { Wye Park } \\
\text { (Columbia Point) }\end{array}$ & 3 & 105,926 & 42,500 & 39,894 & 53,800 & 54,600 & 61,000 & -6.1 \\
\hline $\begin{array}{l}\text { Sacajawea State } \\
\text { Park }\end{array}$ & 3 & 15,403 & 24,300 & 9,027 & 32,100 & 27,200 & 25,600 & 9.5 \\
\hline $\begin{array}{l}\text { Integration Project } \\
\text { Area } 3\end{array}$ & 3 & $3,792,675$ & $3,425,000$ & $3,216,140$ & $3,170,100$ & $3,089,300$ & $3,353,500$ & -1.7 \\
\hline McNary Dam & 4 & 410,877 & 645,900 & 468,225 & 592,300 & 401,700 & 347,500 & -2.2 \\
\hline Hood Park & 4 & 259,723 & 267,000 & 243,056 & 212,500 & 226,800 & 221,600 & -2.1 \\
\hline $\begin{array}{l}\text { McNary Wildlife } \\
\text { Area }\end{array}$ & 4 & 90,608 & 73,300 & 77,818 & 81,900 & 81,400 & 74,900 & -2.5 \\
\hline Warehouse Beach & 4 & 47,312 & 39,100 & 96,583 & 39,000 & 81,800 & 63,900 & 5.0 \\
\hline $\begin{array}{l}\text { Hat Rock State } \\
\text { Park }\end{array}$ & 4 & 45,474 & 44,200 & 32,355 & 37,000 & 30,500 & 39,100 & -2.0 \\
\hline $\begin{array}{l}\text { Madame Dorion } \\
\text { Park }\end{array}$ & 4 & 36,940 & 39,400 & 38,562 & 43,600 & 36,500 & 35,900 & -0.4 \\
\hline $\begin{array}{l}\text { McNary Beach } \\
\text { Park }\end{array}$ & 4 & 37,715 & 30,600 & 40,876 & 32,500 & 30,900 & 33,100 & -1.7 \\
\hline $\begin{array}{l}\text { McNary Habitat } \\
\text { Management Units }\end{array}$ & 4 & 21,122 & 24,000 & 22,993 & 26,300 & 20,600 & 20,800 & -0.2 \\
\hline Hover Park & 4 & 8,100 & 4,700 & 32,500 & 28,700 & 30,600 & 24,200 & 28.4 \\
\hline $\begin{array}{l}\text { McNary Yacht } \\
\text { Club (Hat Rock) }\end{array}$ & 4 & 7,826 & 7,400 & 10,734 & 7,900 & 6,700 & 8,100 & 0.5 \\
\hline $\begin{array}{l}\text { McNary National } \\
\text { Wildlife Refuge }\end{array}$ & 4 & 5,144 & 3,100 & 8,483 & 14,600 & 13,100 & 8,600 & 9.6 \\
\hline $\begin{array}{l}\text { Walla Walla Yacht } \\
\text { Club (Port Kelley) }\end{array}$ & 4 & 5,973 & 5,400 & 5,940 & 5,100 & 1,400 & 500 & -13.1 \\
\hline $\begin{array}{l}\text { Integration Project } \\
\text { Area } 4\end{array}$ & 4 & 976,814 & $1,184,100$ & $1,078,125$ & $1,121,400$ & 962,000 & 878,200 & -1.4 \\
\hline Lake Wallula Total & $3 \& 4$ & $4,769,489$ & $4,609,100$ & $4,294,265$ & $4,291,500$ & $4,051,300$ & $4,231,700$ & -1.6 \\
\hline
\end{tabular}


Table 1.2. Summary of Boat Angling Effort in the Hanford Reach

\begin{tabular}{|c|c|c|c|c|c|c|c|}
\hline \multirow[b]{2}{*}{ Dates } & \multirow[b]{2}{*}{ Area } & \multicolumn{3}{|c|}{ Effort } & \multicolumn{3}{|c|}{ Species Caught } \\
\hline & & Boats & Anglers & $\begin{array}{c}\text { Pole } \\
\text { Hours }\end{array}$ & Chinook & Jacks & Steelhead \\
\hline \multirow{4}{*}{$\begin{array}{l}08 / 16 / 00 \text { to } \\
11 / 05 / 00\end{array}$} & LeslieGroves & 233 & 466 & 2714 & 52 & 6 & 40 \\
\hline & Ringold & 464 & 1031 & 6369 & 207 & 84 & 86 \\
\hline & Vernita & 1097 & 2635 & 15,703 & 499 & 96 & \\
\hline & Wahluke & 566 & 1317 & 8510 & 324 & 34 & \\
\hline \multicolumn{2}{|c|}{2000 Season Totals } & 2360 & 5449 & 33,296 & 1082 & 220 & 126 \\
\hline \multirow{4}{*}{$\begin{array}{l}08 / 16 / 01 \text { to } \\
10 / 31 / 01\end{array}$} & LeslieGroves & 71 & 149 & 894 & 26 & 4 & \\
\hline & Ringold & 698 & 1531 & 9291 & 397 & 111 & \\
\hline & Vernita & 1214 & 2862 & 17,858 & 1056 & 268 & \\
\hline & Wahluke & 491 & 1187 & 7655 & 396 & 49 & \\
\hline $\begin{array}{l}11 / 06 / 01 \text { to } \\
01 / 27 / 02\end{array}$ & Ringold & $\mathrm{n} / \mathrm{a}$ & 228 & 917 & -- & -- & 94 \\
\hline \multicolumn{2}{|c|}{2001 Season Totals } & 2474 & 5808 & 35,721 & 1849 & 428 & 94 \\
\hline
\end{tabular}

Table 1.3. 2000-2001 Summary of Bank Angling Effort in the Hanford Reach

\begin{tabular}{|c|c|c|c|c|c|c|}
\hline \multirow[b]{2}{*}{ Dates } & \multirow[b]{2}{*}{ Area } & \multicolumn{2}{|c|}{ Effort } & \multicolumn{3}{|c|}{ Species Caught } \\
\hline & & Anglers & $\begin{array}{c}\text { Pole } \\
\text { Hours }\end{array}$ & Chinook & Jacks & Steelhead \\
\hline $08 / 16 / 00$ to $11 / 05 / 00$ & Ringold & 396 & 1093 & 15 & 10 & 77 \\
\hline \multicolumn{2}{|l|}{2000 Season Total } & 396 & 1093 & 15 & 10 & 77 \\
\hline $04 / 21 / 01$ to $5 / 14 / 01$ & Ringold & 1642 & 7275 & 280 & 1 & -- \\
\hline $08 / 16 / 01$ to $10 / 31 / 01$ & Ringold & 306 & 797 & 19 & 18 & -- \\
\hline $11 / 06 / 01$ to $01 / 27 / 02$ & Ringold & 482 & 980 & 1 & 1 & 54 \\
\hline \multicolumn{2}{|l|}{2001 Season Total } & 2430 & 9052 & 300 & 20 & 54 \\
\hline
\end{tabular}


Table 1.4. WDFW Northern Pikeminnow Sport-Reward Fishery Program Summary

\begin{tabular}{|l|c|c|c|c|}
\hline \multirow{2}{*}{ Check Station } & \multicolumn{2}{|c|}{2001} & \multicolumn{2}{c|}{2000} \\
\cline { 2 - 5 } & Anglers $^{(\mathbf{a})}$ & Catch $^{*}$ & Anglers $^{(\mathbf{a})}$ & Catch \\
\hline Ringold & 60 & 2899 & $\mathrm{n} / \mathrm{a}$ & $\mathrm{n} / \mathrm{a}$ \\
\hline Columbia Point & 1333 & 8420 & 1333 & 8420 \\
\hline Vernita & 1759 & 25,519 & 1759 & 25,519 \\
\hline Total & $\mathbf{3 1 5 2}$ & $\mathbf{3 6 , 8 3 8}$ & $\mathbf{3 7 5 9}$ & $\mathbf{2 5 , 7 7 7}$ \\
\hline
\end{tabular}

(a) Number of registered anglers by station. 


\subsection{Objectives}

This study specifically seeks to provide data to answer the following:

- How much recreational use of the Columbia River is occurring?

- What types of recreational activities occur and how are these activities manifested in trips to the river?

- What are the duration and frequency of river-based activities?

- What are the characteristics of boat fishing versus bank fishing, and what fish species are taken?

- How much do river recreationists spend on a typical visit to the river? How do expenditures vary by river activity and trip origin?

- What are the alternatives to current recreation on the Columbia? If the recreation activity on the Columbia were to change because of perceived hazards from contamination, would spending patterns also shift? 


\subsection{Methods}

This section describes the dimensions of the study area and the data collection approach used to satisfy the objectives.

\subsection{Recreation Survey Study Area}

The designated study area for the 2001 Columbia River Recreation Survey conforms to that designated for study in the broader Integration Project (Figure 3.1). The stretch of river reaching from Priest Rapids Dam to McNary Dam was divided into four sections. Beginning farthest upstream, Area 1 extends downstream to the power line crossing near river mile 364. Area 2 continues downstream from that point to the City of Richland Snyder Street water intake station. Area 3 continues downstream from that point to the confluence of the Snake River with the Columbia River. Area 4 is comprised of the stretch of Lake Wallula running upstream from the confluence of the Snake and Columbia rivers to McNary Dam.

The first significant river access points in Area 1 are the primitive boat launches and the campgrounds near the Vernita Bridge (Hwy 24) on the north shore of the river (Grant County). This area is used primarily for fishing and dispersed camping, as it has easy access to the river and no permanent facilities of any kind. Downstream from the bridge flows the most primitive section of the Hanford Reach, bordered on the south by the Hanford Site and on the north by the Hanford Reach National Monument. The only other public access is gained via the Wahluke boat launch on the east bank (Franklin County) of the river near river mile 370 .

Area 2 has two principal river access points. A primitive boat launch near the Ringold Hatchery on the east bank (Franklin County) provides access on the north end of Area 2. The public boat launch at Leslie Groves Park on the west bank (Benton County) on the north end of Area 3 provides access to the south end of Area 2. This area forms the last section of the Hanford Reach, as the Lake Wallula pool extends to the Snyder Street intake station. Fishing and water skiing are the principal recreational activities favored in Area 2, as no other public facilities are present.

Area 3 contains the most concentrated amount of recreational use in the Integration Project study area. Bordered by Richland, Kennewick, and Pasco, the majority of river shore is developed into parkland and public access on both sides of the river. These parks include Leslie Groves Park, Howard Amon Park, Columbia Point, Bateman Island, Columbia Park, and Two Rivers Park on the Benton County side and Chiawana Park, Schlagel Park, and Sacagawea State Park on the Franklin County side. All forms of river recreation are widely enjoyed in Area 3.

Area 4 is primarily accessed from the parks and launches around McNary Dam; however, some access to the upper end of this area is gained from Hood Park (Walla Walla County) or from Two Rivers Park (Benton County). The survey did not intentionally sample recreation participants in Area 4. Time and resources were devoted to getting adequate sample sizes for the areas closer to potential contaminant plume sources and where the greatest amounts of river recreation occur. 


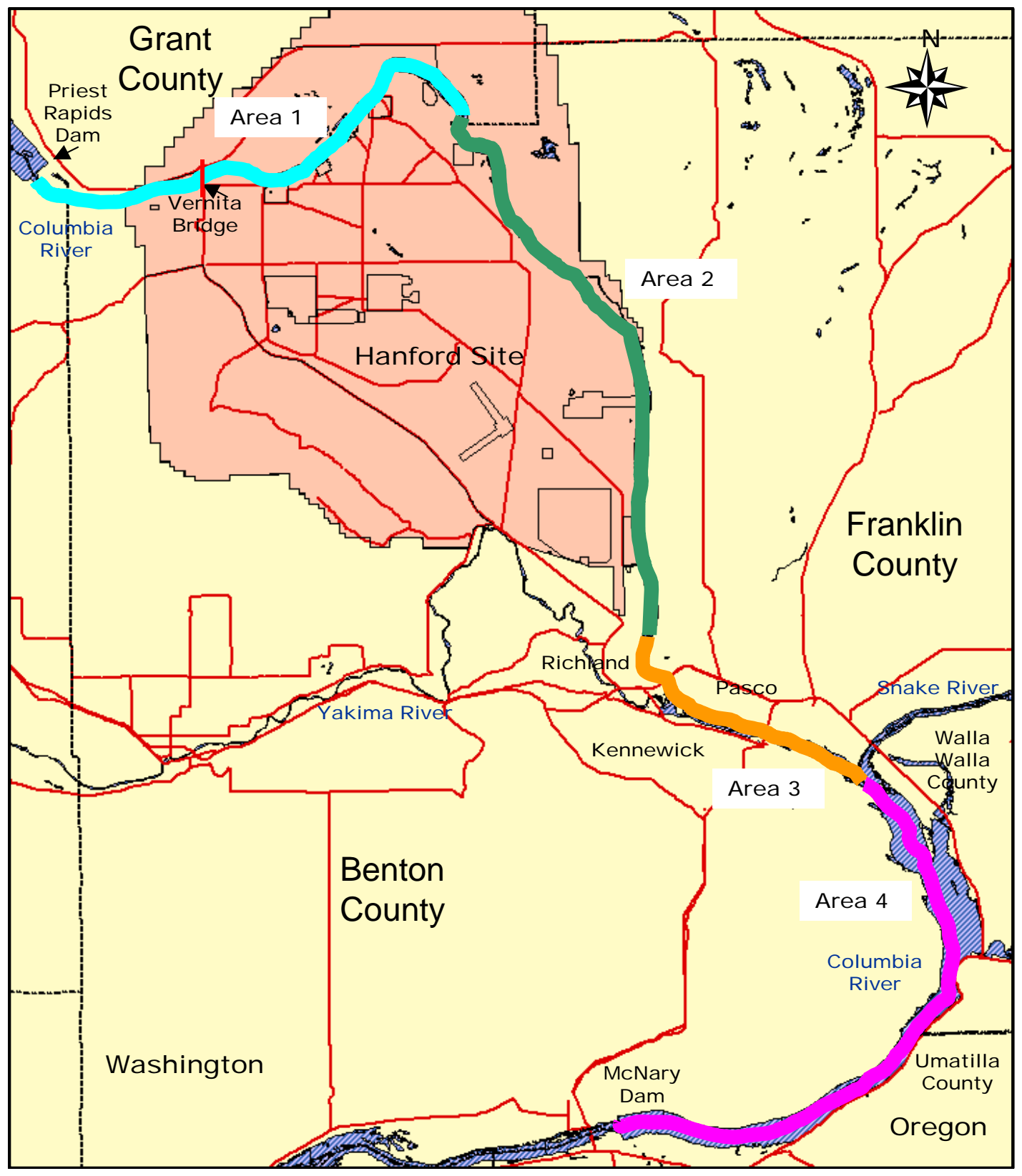

Figure 3.1. Groundwater/Vadose Zone Integration Project Study Area with the Regions for the 2001 Columbia River Recreation Survey ${ }^{(a)}$

(a) Hanford Reach National Monument was established in 2000; however, monument boundaries have not been made official as of this publication and are not shown on Figure 3.1. 


\subsection{Summer Study Data Collection}

During the summer of 2001, DOE commissioned a survey of Columbia River recreationists. The survey (included in Appendix B) was conducted in two parts. First, trained 2-person teams of interviewers conducted personal on-site interviews with parties of recreationists to gather information concerning time on site, activity participation, visitation habits, and trip expenditures. Second, field observations were recorded on standardized forms (also in Appendix B) at the various survey points to record general conditions, person counts, and other data. Results from the analysis of survey responses and field observations form the thrust of this report.

Sampling for the survey interview and the field observations followed a maximum-effort approach. During the early-July through mid-August study period, 2-person data collection teams were generally deployed serially in the field. They entered predetermined recreation sites and attempted to survey as many parties as time and cooperation would allow. They also made field observations during 15 minutes of each hour spent on-site. Each team was given a route consisting of various river access points/parks to investigate during their shift. These routes were developed to assure full coverage of Area 3, while also assuring adequate coverage of Areas 1 and 2.

The survey received 256 valid responses during approximately 7 weeks (early July to mid-August) of field time in the summer of 2001. Sampling favored the areas having the highest densities of recreationists and those areas closest to plume sources. During that time, field observers recorded 396 valid field observations. The study also intended to collect data on the broadest array of river-based recreation activities possible. This effort was constrained by the availability of the data collection team, as they were limited to the July-August period previously indicated. As a result, traditional summer activities, like boating, swimming, water skiing, and some fishing, were well sampled.

However, the river hosts significant levels of recreation during other times of the year. In particular, various fishing and waterfowl hunting seasons occur outside the data collection window of this study. Though not represented in this report, those activities are acknowledged as significant in the total riverbased recreation picture. This conclusion is particularly true when considering the total economic impact of river recreation expenditures. Table 3.1 summarizes the data collection effort by Integration Project river area. Table 3.2 distributes these results by county. 
Table 3.1. Data Collection Effort by River Area during Summer 2001 Study Period

\begin{tabular}{|c|c|c|c|c|c|c|c|c|c|c|}
\hline $\begin{array}{c}\text { River Area of } \\
\text { Data Collection }\end{array}$ & $\begin{array}{c}\text { Field Data } \\
\text { Observations }\end{array}$ & $\begin{array}{c}\text { Survey } \\
\text { Observations }\end{array}$ & $\begin{array}{c}\text { Field Count of } \\
\text { People }\end{array}$ & $\begin{array}{c}\text { Survey } \\
\text { Count of } \\
\text { People }\end{array}$ & \begin{tabular}{|c|} 
Field \\
Sampling \\
Effort \\
$(\%)$
\end{tabular} & \begin{tabular}{|c|} 
Survey \\
Sampling \\
Effort \\
$(\%)$
\end{tabular} & $\begin{array}{c}\text { Surveyed/Count } \\
\text { of People }(\%)\end{array}$ & $\begin{array}{l}\text { People/Field } \\
\text { Observation }\end{array}$ & $\begin{array}{c}\text { People/Survey } \\
\text { Observation }\end{array}$ & \begin{tabular}{|c}
$\begin{array}{c}\text { Surveys } \\
\text { of Field } \\
\text { Visits } \\
(\%)\end{array}$ \\
\end{tabular} \\
\hline Area 1 & 27 & 3 & 53 & 9 & 6.8 & 1.2 & 17.0 & 2.0 & 3.0 & 11.1 \\
\hline Area 2 & 32 & 7 & 172 & 21 & 8.1 & 2.7 & 12.2 & 5.4 & 3.0 & 21.9 \\
\hline Area 3 & 337 & 246 & 10,792 & 1,251 & 85.1 & 96.1 & 11.6 & 32.0 & 5.1 & 73.0 \\
\hline Total & 396 & 256 & 11,017 & 1,281 & 100.0 & 100.0 & 11.6 & 27.8 & 5.0 & 64.6 \\
\hline
\end{tabular}

Table 3.2. Data Collection Effort by County during Summer 2001 Study Period

\begin{tabular}{|c|c|c|c|c|c|c|c|c|c|c|}
\hline $\begin{array}{l}\text { County of } \\
\text { Data } \\
\text { Collection }\end{array}$ & $\begin{array}{c}\text { Field Data } \\
\text { Observations }\end{array}$ & $\begin{array}{c}\text { Survey } \\
\text { Observations }\end{array}$ & $\begin{array}{c}\text { Field } \\
\text { Count of } \\
\text { People }\end{array}$ & $\begin{array}{c}\text { Survey } \\
\text { Count of } \\
\text { People }\end{array}$ & $\begin{array}{c}\text { Field } \\
\text { Sampling } \\
\text { Effort }(\%)\end{array}$ & $\begin{array}{c}\text { Survey } \\
\text { Sampling } \\
\text { Effort (\%) }\end{array}$ & $\begin{array}{c}\text { Surveyed/Count } \\
\text { of People \% }\end{array}$ & $\begin{array}{l}\text { People/Field } \\
\text { Observation }\end{array}$ & $\begin{array}{c}\text { People/Survey } \\
\text { Observation }\end{array}$ & $\begin{array}{c}\begin{array}{c}\text { Surveys } \\
\text { of Field } \\
\text { Visits }\end{array} \\
(\%)\end{array}$ \\
\hline Benton & 237 & 213 & 8,873 & 1,054 & 59.8 & 83.2 & 11.9 & 37.4 & 4.9 & 89.9 \\
\hline Franklin & 113 & 31 & 1,844 & 180 & 28.5 & 12.1 & 9.8 & 16.3 & 5.8 & 27.4 \\
\hline Walla Walla & 19 & 9 & 247 & 38 & 4.8 & 3.5 & 15.4 & 13.0 & 4.2 & 47.4 \\
\hline Grant & 27 & 3 & 53 & 9 & 6.8 & 1.2 & 17.0 & 2.0 & 3.0 & 11.1 \\
\hline Total & 396 & 256 & 11,017 & 1,281 & 100.0 & 100.0 & 11.6 & 27.8 & 5.0 & 64.6 \\
\hline
\end{tabular}




\subsection{Results}

This section presents the findings of the study and a summary of the data in tabular form. These results are organized according to the principal questions of the survey.

\subsection{Trip Characteristics}

Table 4.1 indicates that over 80 percent of those surveyed originated their trip to the Columbia River study area from within the study area counties (Benton, Franklin, Walla Walla, and Umatilla). Of that 80 percent, Table 4.2 indicates that almost 80 percent reside in Benton County. The year 2000 population of Benton and Franklin counties is split about 75 percent -25 percent. The survey data collection resulted in a sample distribution of observations that approximates the population distribution. Grant County borders the study area, but relatively few visitors come to the study area from here.

\subsection{Length of Stay}

For visitors from outside areas, the survey elicited the length of their trip to the area for participation in river-based recreation. Local residents were assumed to return to their home residences each day essentially making single-day trips to the river. The results vary widely, as sample sizes are small and the effect of individual responses is relatively large. Table 4.3 indicates that on average (based on 48 observations), visitors from outside the study area spend more than 6 days on their trip.

Respondents were also asked how many days per year they engaged in river-based recreation. For local residents, this number approaches 60 visits per year, and across the sample, the average group visits the river for recreation more than 47 days per year (Table 4.4).

\subsection{Party Size}

The survey gathered information about the size and makeup of the parties surveyed. Those results are presented by Integration Project river area in Table 4.5. The average river recreation party consists of three adults accompanied by two children.

\subsection{River Recreation Activities}

Respondents were asked to identify the river-based recreation activities they were pursuing during their trip to the river. They also identified the principal or main activity and the duration of all activities during the trip. Table 4.6 presents results in terms of hours and recreation visitor days (RVD). An RVD is an accepted federal measure of recreation participation used when specific time onsite is known - in this case hours per activity. One RVD is equivalent to any 12 hours of activity. For example, one-person camping overnight, spending 24 hours onsite equates to $2 \mathrm{RVD}$, while 24 people sightseeing at a site for 1 hour each also equates to 2 RVD. 
Results presented in Table 4.7 can be used to characterize a composite trip. A composite trip is simply the sum of all activity participation during the trip in terms of hours. For example, the weighted average composite trip consists of 1.5 hours of swimming, 0.9 hours of boating, 0.8 hours of water-skiing, 0.4 hours of bank fishing, 0.3 hours of boat fishing, and 1.6 hours of other activities, for a total of 5.6 hours spent onsite.

Composite trip information is more useful when stratified by principal activity. The weighted average trip by definition does not necessarily represent any specific or typical trip to the river.

Across the sample, picnicking, boating, water-skiing, and swimming were the most cited principal recreation activities. However, nearly 24 percent of respondents could not or chose not to indicate any primary activity. Figure 4.1 depicts the distribution of recreation activity participation.

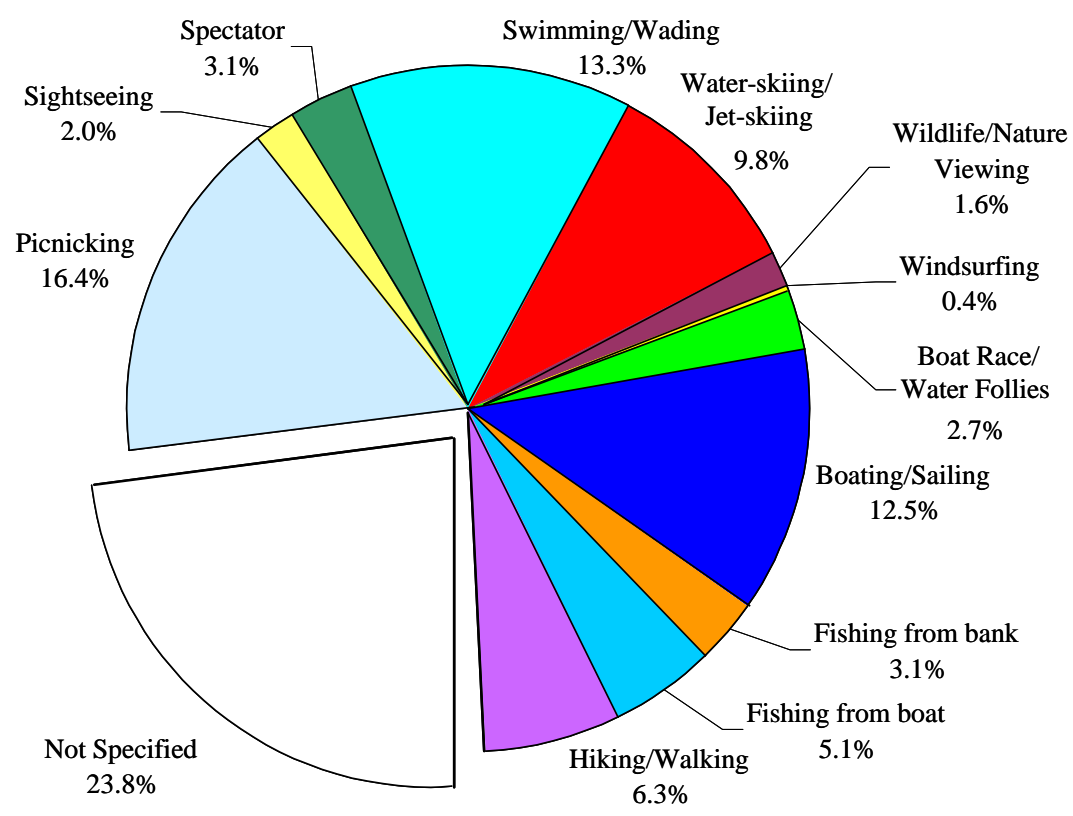

Figure 4.1. Distribution of Respondents by Primary Activity $(n=256)$

Tables 4.8 through 4.28 facilitate characterization of composite trips by river area, and by recreation activity in terms of activity duration. Statistical tables appear in Appendix C.

Tables 4.23 through 4.28 detail the respondents' choice of alternative primary activities. Those indicating "other" to the request for primary activity were asked to indicate their primary activity from several other non-river-contact activities. Note that totals are affected by rounding. Statistical tables appear in Appendix C. 
The field observations of river recreation activities across the study area are characterized in Table 4.29. Results are presented as 7-day week profiles, providing a view by activity of the variation in weekday recreation patterns. Counts presented constitute site-level averages across $n$ site data collection visits by researchers. Essentially, these results indicate the average site-level composite recreation activity participation level on a given weekday. These results are detailed further by river area in Tables 4.30 through 4.32. "Other" observed activities include sightseeing, walking, picnicking, and field sports, etc. occurring in riverside parks. Statistical tables appear in Appendix C.

\subsection{River Areas}

Survey respondents were also asked to identify what proportion of their current trip was spent in which Integration Project river area(s). Those results are presented in Table 4.33. On average, respondents entering Area 1 spent 75 percent of their time there, and those entering Area 2 spent 69.4 percent of their time in Area 2. This indicates that some level of transition from area to area is likely in Areas 1 and 2, but this is not the case in Area 3, where those entering spend 97.9 percent of their time. Statistical tables appear in Appendix C.

\subsection{Fishing}

Of those sampled, 31 parties participated in some level of fishing activity. Those respondents were asked to identify which species they were pursuing, and they could indicate multiple species from the choices displayed in Table 4.34. Because the survey was conducted outside of the window of primary spring and fall fishing seasons, results are presented in aggregate only and are probably not truly representative of fishing in the study area. The greatest proportion of respondents indicated they were fishing for anything they could get.

\subsection{Recreation Expenditures}

A principal reason for the survey was to develop baseline expenditure information for the SAC economic impact model. Of the 256 valid survey responses, 219 provided expenditure information. It was not possible to determine from the responses what proportion of respondents actually made no expenditures associated with their trip and those that declined to provide expenditure information. Table 4.35 summarizes the aggregate expenditure profile for Columbia River recreationists in terms of total trip expenditures and those accruing to businesses and agencies local to the study area. Making this determination provides an estimate of recreation-based demand leakage needed to temper economic impact estimates.

Expenditure results are further detailed by activity in Table 4.36 ( $\mathrm{a}$ and $\mathrm{b}$ ). Respondents report expenditures in excess of $\$ 300$ per party, per trip, for boating, fishing, and Water Follies-related trips. Of those, fishing is the most locally intensive for the economy with over 80 percent of expenditures occurring inside the Benton-Franklin County area. Table 4.37 presents these results by visitor point of origin. 


\subsection{Recreation Alternatives}

Another objective of the survey was to determine the choices available to river recreation participants in the study area. Specifically, respondents were asked to identify where they would go and what activities they would do if they could not or chose not to visit the particular river stretch they had visited the day of the interview. Of the 256 valid responses, 200 (78.1 percent) indicated their party would choose an alternate location to recreate. Of those 200 parties, 111 (55.5 percent) provided information about which activities they would pursue at the alternative location. Of that group, 16 parties (14.4 percent) indicated they would switch to different activities at the alternative site. Due to significant non-response, these results are not robust across all river areas and activities. Results from the follow-up with those parties indicating they would stay in the same area were overwhelmed by nonresponse.

Table 4.1. Visitor Origin and Party Size Characteristics

\begin{tabular}{|l|c|c|c|c|c|c|}
\hline \multicolumn{1}{|c|}{ Area } & People & Parties & $\begin{array}{c}\text { Mean } \\
\text { Size }\end{array}$ & SD & $\begin{array}{c}\text { People } \\
(\boldsymbol{\%})\end{array}$ & $\begin{array}{c}\text { Parties } \\
(\boldsymbol{\%})\end{array}$ \\
\hline Other Areas & 54 & 12 & 4.5 & 2.5 & 4.2 & 4.7 \\
\hline Oregon & 15 & 3 & 5.0 & 4.4 & 1.2 & 1.2 \\
\hline Study Area & 1060 & 208 & 5.1 & 4.1 & 82.7 & 81.3 \\
\hline Eastern WA & 82 & 19 & 4.3 & 2.8 & 6.4 & 7.4 \\
\hline Western WA & 70 & 14 & 5.0 & 3.8 & 5.5 & 5.5 \\
\hline Total & 1281 & 256 & 5.0 & 3.9 & & \\
\hline \hline
\end{tabular}

Table 4.2. Visitor Origin and Party Size Characteristics for Study Area Residents

\begin{tabular}{||l|c|c|c|c|c|c||}
\hline Study Area & People & Parties & $\begin{array}{c}\text { Mean } \\
\text { Size }\end{array}$ & SD & $\begin{array}{c}\text { People } \\
(\%)\end{array}$ & $\begin{array}{c}\text { Parties } \\
(\%)\end{array}$ \\
\hline Umatilla & 5 & 1 & 5.0 & 0.0 & 0.5 & 0.5 \\
\hline Benton & 836 & 164 & 5.1 & 4.2 & 78.9 & 78.8 \\
\hline Franklin & 213 & 40 & 5.3 & 3.9 & 20.1 & 19.2 \\
\hline Walla Walla & 6 & 3 & 2.0 & 1.0 & 0.6 & 1.4 \\
\hline Total & 1060 & 208 & 5.1 & 4.1 & & \\
\hline
\end{tabular}


Table 4.3. Trip Length of Stay by Visitor Origin

\begin{tabular}{|l|c|c|c|c|c|c|l||}
\hline Trip Origination & $\begin{array}{c}\text { Total } \\
\text { Trip } \\
\text { Days }\end{array}$ & People & Parties & $\begin{array}{c}\text { Party } \\
\text { Size }\end{array}$ & $\begin{array}{c}\text { Average } \\
\text { Days } \\
\text { this Trip }\end{array}$ & $\begin{array}{c}\text { Standard } \\
\text { Deviation }\end{array}$ & $\begin{array}{c}\text { Days } \\
(\%)\end{array}$ \\
\hline Other Areas & 223 & 54 & 12 & 4.5 & 18.6 & 41.7 & 76.1 \\
\hline Oregon & 9 & 15 & 3 & 5.0 & 3.0 & 0.0 & 3.1 \\
\hline Eastern WA & 22 & 82 & 19 & 4.3 & 1.2 & 0.8 & 7.5 \\
\hline Western WA & 39 & 70 & 14 & 5.0 & 2.8 & 1.8 & 13.3 \\
\hline Average & 293 & 221 & 48 & 4.6 & 6.1 & 21.4 & \\
\hline
\end{tabular}

Table 4.4. River Recreation Visits per Year by Respondent Origin

\begin{tabular}{||l|c|c|c|c||}
\hline \multicolumn{1}{|c|}{ Area } & $\begin{array}{c}\text { Reported River } \\
\text { Recreation } \\
\text { Days (Visits) }\end{array}$ & Parties & Visits/Year & SD \\
\hline Benton County & 9528 & 164 & 58.1 & 74.2 \\
\hline Franklin County & 2095 & 40 & 52.4 & 67.1 \\
\hline Eastern WA & 306 & 22 & 13.9 & 14.2 \\
\hline Other Areas & 137 & 12 & 11.4 & 35.1 \\
\hline Western WA & 33 & 14 & 2.4 & 2.5 \\
\hline Oregon & 6 & 4 & 1.5 & 1.0 \\
\hline Average & 12,105 & 256 & 47.3 & 68.3 \\
\hline
\end{tabular}

Table 4.5. Recreation Party Size by River Area

\begin{tabular}{|l|c|c|c|c|c|c|c|c|c|c|}
\hline Area & $\begin{array}{c}\text { Observations } \\
\text { (Parties) }\end{array}$ & $\begin{array}{c}\text { Total } \\
\text { Adults }\end{array}$ & $\begin{array}{c}\text { Total } \\
\text { Kids }\end{array}$ & $\begin{array}{c}\text { Total } \\
\text { People }\end{array}$ & $\begin{array}{c}\text { Adults/ } \\
\text { Party }\end{array}$ & $\begin{array}{c}\text { Standard } \\
\text { Deviation }\end{array}$ & $\begin{array}{c}\text { Kids/ } \\
\text { Party }\end{array}$ & $\begin{array}{c}\text { Standard } \\
\text { Deviation }\end{array}$ & $\begin{array}{c}\text { Average } \\
\text { Party Size }\end{array}$ & $\begin{array}{c}\text { Standard } \\
\text { Deviation }\end{array}$ \\
\hline Area 1 & 5 & 23 & 9 & 32 & 4.6 & 3.0 & 1.8 & 3.5 & 6.4 & 5.6 \\
\hline Area 2 & 17 & 56 & 18 & 74 & 3.3 & 2.0 & 1.1 & 2.1 & 4.4 & 3.5 \\
\hline Area 3 & 240 & 713 & 513 & 1226 & 3.0 & 2.1 & 2.1 & 2.5 & 5.1 & 4.0 \\
\hline Area 4 & 6 & 20 & 14 & 34 & 3.3 & 2.0 & 2.3 & 2.7 & 5.7 & 4.1 \\
\hline $\begin{array}{l}\text { Study } \\
\text { Area }\end{array}$ & 268 & 812 & 554 & 1366 & 3.0 & 2.1 & 2.1 & 2.5 & 5.1 & 3.9 \\
\hline
\end{tabular}

(a) Parties could report activity in more than one area, so totals sum to more than the total number of survey observations. 
Table 4.6. Recreation Activity Duration by Primary Activity

\begin{tabular}{|l|c|c|c|c|c|c|c|c||}
\hline Primary Activity & Swimming & Boating & $\begin{array}{c}\text { Water- } \\
\text { skiing }\end{array}$ & $\begin{array}{c}\text { Bank } \\
\text { Fishing }\end{array}$ & $\begin{array}{c}\text { Boat } \\
\text { Fishing }\end{array}$ & Other & $\begin{array}{c}\text { Hours/ } \\
\text { Trip }\end{array}$ & $\begin{array}{c}\text { RVDs/ } \\
\text { Trip }\end{array}$ \\
\hline $\begin{array}{l}\text { Boating/ } \\
\text { Sailing }\end{array}$ & 1.5 & 4.8 & 0.6 & 0.0 & 0.1 & 1.3 & 8.3 & 0.693 \\
\hline Fishing from Bank & 0.3 & 0.0 & 0.0 & 6.4 & 0.0 & 0.3 & 6.9 & 0.573 \\
\hline Fishing from Boat & 0.2 & 0.2 & 0.2 & 0.0 & 6.1 & 0.0 & 6.7 & 0.558 \\
\hline Not Specified & 1.6 & 0.6 & 0.7 & 0.2 & 0.2 & 1.8 & 5.1 & 0.424 \\
\hline Other & 0.5 & 0.2 & 0.4 & 0.0 & 0.0 & 3.1 & 4.2 & 0.350 \\
\hline $\begin{array}{l}\text { Swimming/ } \\
\text { Wading }\end{array}$ & 3.0 & 0.2 & 0.1 & 0.4 & 0.0 & 1.4 & 5.1 & 0.424 \\
\hline $\begin{array}{l}\text { Waterskiing/ } \\
\text { Jetskiing }\end{array}$ & 1.6 & 0.2 & 4.0 & 0.0 & 0.0 & 0.3 & 6.1 & 0.510 \\
\hline Weighted Average & 1.5 & 0.9 & 0.8 & 0.3 & 0.4 & 1.6 & 5.6 & 0.466 \\
\hline $\begin{array}{l}\text { Recreation Visitor } \\
\text { Days }\end{array}$ & 0.124 & 0.078 & 0.068 & 0.026 & 0.033 & 0.135 & 0.466 & \\
\hline
\end{tabular}

Table 4.7. Composite Trip Activity Duration (Hours/Trip) by River Area

\begin{tabular}{|c|c|c|c|c|c|c|c|c|}
\hline $\begin{array}{c}\text { Composite } \\
\text { Trip }\end{array}$ & Swimming & Boating & $\begin{array}{l}\text { Water- } \\
\text { skiing }\end{array}$ & $\begin{array}{c}\text { Bank } \\
\text { Fishing }\end{array}$ & $\begin{array}{c}\text { Boat } \\
\text { Fishing }\end{array}$ & $\begin{array}{c}\text { Other } \\
\text { Activities }\end{array}$ & $\begin{array}{c}\text { Composite } \\
\text { Trip }\end{array}$ & Observations \\
\hline Area 1 & 1.2 & 1.2 & 0.0 & 1.6 & 1.6 & 1.8 & 7.4 & 5 \\
\hline Area 2 & 0.9 & 1.7 & 0.9 & 0.9 & 2.9 & 0.8 & 8.1 & 17 \\
\hline Area 3 & 1.5 & 1.0 & 0.8 & 0.2 & 0.2 & 1.7 & 5.4 & 240 \\
\hline Area 4 & 1.8 & 2.0 & 1.3 & 0.0 & 2.2 & 2.0 & 9.3 & 6 \\
\hline Study Area ${ }^{(a)}$ & 1.5 & 1.0 & 0.8 & 0.3 & 0.4 & 1.7 & 5.7 & 268 \\
\hline
\end{tabular}

(a) Parties can report activity in more than one area, so totals sum to more than the total number of survey observations. 
Table 4.8. Boating Trip Activity Duration (Hours/Trip) by River Area

\begin{tabular}{|l|c|c|c|c|c|c|c|c||}
\hline \multicolumn{1}{|c|}{ Boating } & Swimming & Boating & Waterskiing & $\begin{array}{c}\text { Bank } \\
\text { Fishing }\end{array}$ & $\begin{array}{c}\text { Boat } \\
\text { Fishing }\end{array}$ & $\begin{array}{c}\text { Other } \\
\text { Activities }\end{array}$ & $\begin{array}{c}\text { Composite } \\
\text { Trip }\end{array}$ & Observations \\
\hline Area 1 & 0.0 & 3.0 & 0.0 & 0.0 & 0.0 & 0.5 & 3.5 & 2 \\
\hline Area 2 & 0.7 & 4.1 & 0.3 & 0.0 & 0.4 & 1.6 & 7.1 & 7 \\
\hline Area 3 & 1.5 & 4.1 & 0.8 & 0.0 & 0.3 & 1.7 & 8.4 & 56 \\
\hline Area 4 & 2.5 & 6.0 & 1.0 & 0.0 & 2.0 & 4.0 & 15.5 & 2 \\
\hline Study Area & 1.4 & 4.2 & 0.7 & 0.0 & 0.3 & 1.7 & 8.4 & 67 \\
\hline
\end{tabular}

Table 4.9. Swimming Trip Activity Duration (Hours/Trip) by River Area

\begin{tabular}{|l|c|c|c|c|c|c|c|c||}
\hline Swimming & Swimming & Boating & Waterskiing & $\begin{array}{c}\text { Bank } \\
\text { Fishing }\end{array}$ & $\begin{array}{c}\text { Boat } \\
\text { Fishing }\end{array}$ & $\begin{array}{c}\text { Other } \\
\text { Activities }\end{array}$ & $\begin{array}{c}\text { Composite } \\
\text { Trip }\end{array}$ & Observations \\
\hline Area 1 & 6.0 & 0.0 & 0.0 & 0.0 & 0.0 & 8.0 & 14.0 & 1 \\
\hline Area 2 & 3.8 & 2.3 & 2.5 & 0.0 & 0.0 & 2.3 & 10.8 & 4 \\
\hline Area 3 & 2.6 & 1.0 & 0.9 & 0.3 & 0.1 & 2.0 & 6.8 & 141 \\
\hline Area 4 & 2.8 & 3.0 & 2.0 & 0.0 & 1.0 & 3.0 & 11.8 & 4 \\
\hline Study Area & 2.7 & 1.0 & 0.9 & 0.3 & 0.1 & 2.1 & 7.1 & 150 \\
\hline
\end{tabular}

Table 4.10. Bank Fishing Trip Activity Duration (Hours/Trip) by River Area

\begin{tabular}{|l|c|c|c|c|c|c|c|c||}
\hline $\begin{array}{c}\text { Bank } \\
\text { Fishing }\end{array}$ & Swimming & Boating & $\begin{array}{c}\text { Water- } \\
\text { skiing }\end{array}$ & $\begin{array}{c}\text { Bank } \\
\text { Fishing }\end{array}$ & $\begin{array}{c}\text { Boat } \\
\text { Fishing }\end{array}$ & $\begin{array}{c}\text { Other } \\
\text { Activities }\end{array}$ & $\begin{array}{c}\text { Composite } \\
\text { Trip }\end{array}$ & Observations \\
\hline Area 1 & 0.0 & 0.0 & 0.0 & 8.0 & 0.0 & 0.0 & 8.0 & 1 \\
\hline Area 2 & 0.0 & 0.0 & 0.0 & 8.0 & 0.0 & 0.0 & 8.0 & 2 \\
\hline Area 3 & 0.8 & 0.0 & 0.3 & 4.8 & 0.0 & 0.7 & 6.4 & 12 \\
\hline Area 4 & -- & -- & -- & -- & -- & -- & 0.0 & -- \\
\hline Study Area & 0.6 & 0.0 & 0.2 & 5.4 & 0.0 & 0.5 & 6.7 & 15 \\
\hline
\end{tabular}


Table 4.11. Boat Fishing Trip Activity Duration (Hours/Trip) by River Area

\begin{tabular}{|l|c|c|c|c|c|c|c|c||}
\hline Boat Fishing & Swimming & Boating & $\begin{array}{c}\text { Water- } \\
\text { skiing }\end{array}$ & $\begin{array}{c}\text { Bank } \\
\text { Fishing }\end{array}$ & $\begin{array}{c}\text { Boat } \\
\text { Fishing }\end{array}$ & $\begin{array}{c}\text { Other } \\
\text { Activities }\end{array}$ & $\begin{array}{c}\text { Composite } \\
\text { Trip }\end{array}$ & Observations \\
\hline Area 1 & 0.0 & 0.0 & 0.0 & 0.0 & 8.0 & 0.0 & 8.0 & 1 \\
\hline Area 2 & 0.0 & 0.8 & 0.0 & 0.0 & 8.3 & 0.0 & 9.2 & 6 \\
\hline Area 3 & 0.5 & 2.0 & 0.4 & 0.0 & 3.8 & 0.9 & 7.6 & 10 \\
\hline Area 4 & 0.7 & 2.0 & 0.7 & 0.0 & 4.3 & 2.7 & 10.3 & 3 \\
\hline Study Area & 0.4 & 1.6 & 0.3 & 0.0 & 5.5 & 0.9 & 8.5 & 20 \\
\hline
\end{tabular}

Table 4.12. Waterskiing Trip Activity Duration (Hours/Trip) by River Area

\begin{tabular}{||c|c|c|c|c|c|c|c|c||}
\hline $\begin{array}{c}\text { Water- } \\
\text { skiing }\end{array}$ & Swimming & Boating & $\begin{array}{c}\text { Water- } \\
\text { skiing }\end{array}$ & $\begin{array}{c}\text { Bank } \\
\text { Fishing }\end{array}$ & $\begin{array}{c}\text { Boat } \\
\text { Fishing }\end{array}$ & $\begin{array}{c}\text { Other } \\
\text { Activities }\end{array}$ & $\begin{array}{c}\text { Composite } \\
\text { Trip }\end{array}$ & Observations \\
\hline Area 1 & -- & -- & -- & -- & -- & -- & 0.0 & -- \\
\hline Area 2 & 3.7 & 2.3 & 5.0 & 0.0 & 0.0 & 2.3 & 13.3 & 3 \\
\hline Area 3 & 1.8 & 1.3 & 3.6 & 0.1 & 0.1 & 1.7 & 8.6 & 54 \\
\hline Area 4 & 2.0 & 3.0 & 4.0 & 0.0 & 2.0 & 4.0 & 15.0 & 2 \\
\hline Study Area & 1.9 & 1.4 & 3.7 & 0.1 & 0.2 & 1.8 & 9.1 & 59 \\
\hline
\end{tabular}

Table 4.13. Other Activities Trip Activity Duration (Hours/Trip) by River Area

\begin{tabular}{|l|c|c|c|c|c|c|c|c||}
\hline $\begin{array}{c}\text { Other } \\
\text { Activity }\end{array}$ & Swimming & Boating & $\begin{array}{c}\text { Water- } \\
\text { skiing }\end{array}$ & $\begin{array}{c}\text { Bank } \\
\text { Fishing }\end{array}$ & $\begin{array}{c}\text { Boat } \\
\text { Fishing }\end{array}$ & $\begin{array}{c}\text { Other } \\
\text { Activities }\end{array}$ & $\begin{array}{c}\text { Composite } \\
\text { Trip }\end{array}$ & Observations \\
\hline Area 1 & 3.0 & 0.5 & 0.0 & 0.0 & 0.0 & 4.5 & 8.0 & 2 \\
\hline Area 2 & 1.3 & 3.3 & 0.5 & 0.0 & 0.0 & 3.3 & 8.3 & 4 \\
\hline Area 3 & 1.7 & 0.7 & 0.6 & 0.0 & 0.0 & 3.2 & 6.3 & 130 \\
\hline Area 4 & 3.0 & 3.0 & 1.0 & 0.0 & 2.0 & 6.0 & 15.0 & 2 \\
\hline $\begin{array}{l}\text { Study } \\
\text { Area }\end{array}$ & 1.8 & 0.8 & 0.6 & 0.0 & 0.1 & 3.2 & 6.5 & 138 \\
\hline \hline
\end{tabular}


Table 4.14. Picnicking Trip Activity Duration (Hours/Trip) by River Area

\begin{tabular}{|l|c|c|c|c|c|c|c|c||}
\hline Picnicking & Swimming & Boating & $\begin{array}{c}\text { Water- } \\
\text { skiing }\end{array}$ & $\begin{array}{c}\text { Bank } \\
\text { Fishing }\end{array}$ & $\begin{array}{c}\text { Boat } \\
\text { Fishing }\end{array}$ & $\begin{array}{c}\text { Other } \\
\text { Activities }\end{array}$ & $\begin{array}{c}\text { Composite } \\
\text { Trip }\end{array}$ & Observations \\
\hline Area 1 & 3.0 & 0.5 & 0.0 & 0.0 & 0.0 & 4.5 & 8.0 & 2 \\
\hline Area 2 & 1.5 & 4.5 & 1.0 & 0.0 & 0.0 & 4.5 & 11.5 & 2 \\
\hline Area 3 & 2.6 & 0.9 & 1.0 & 0.1 & 0.1 & 3.8 & 8.4 & 58 \\
\hline Area 4 & 3.0 & 3.0 & 1.0 & 0.0 & 2.0 & 6.0 & 15.0 & 2 \\
\hline Study Area & 2.6 & 1.1 & 0.9 & 0.0 & 0.1 & 3.9 & 8.7 & 64 \\
\hline
\end{tabular}

Table 4.15. Water Follies Trip Activity Duration (Hours/Trip) by River Area

\begin{tabular}{||l|c|c|c|c|c|c|c|c||}
\hline $\begin{array}{c}\text { Boat Race/ } \\
\text { Water Follies }\end{array}$ & Swimming & Boating & $\begin{array}{c}\text { Water- } \\
\text { skiing }\end{array}$ & $\begin{array}{c}\text { Bank } \\
\text { Fishing }\end{array}$ & $\begin{array}{c}\text { Boat } \\
\text { Fishing }\end{array}$ & $\begin{array}{c}\text { Other } \\
\text { Activities }\end{array}$ & $\begin{array}{c}\text { Composite } \\
\text { Trip }\end{array}$ & Observations \\
\hline Area 1 & -- & -- & -- & -- & -- & -- & 0.0 & -- \\
\hline Area 2 & -- & -- & -- & -- & -- & -- & 0.0 & -- \\
\hline Area 3 & 1.5 & 0.9 & 0.2 & 0.1 & 0.0 & 5.2 & 7.9 & 11 \\
\hline Area 4 & -- & -- & -- & -- & -- & -- & 0.0 & -- \\
\hline Study Area & 1.5 & 0.9 & 0.2 & 0.1 & 0.0 & 5.2 & 7.9 & 11 \\
\hline
\end{tabular}

Table 4.16. Walking/Hiking Trip Activity Duration (Hours/Trip) by River Area

\begin{tabular}{||l|c|c|c|c|c|c|c|c||}
\hline $\begin{array}{c}\text { Walking/ } \\
\text { Hiking }\end{array}$ & Swimming & Boating & $\begin{array}{c}\text { Water- } \\
\text { skiing }\end{array}$ & $\begin{array}{c}\text { Bank } \\
\text { Fishing }\end{array}$ & $\begin{array}{c}\text { Boat } \\
\text { Fishing }\end{array}$ & $\begin{array}{c}\text { Other } \\
\text { Activities }\end{array}$ & $\begin{array}{c}\text { Composite } \\
\text { Trip }\end{array}$ & Observations \\
\hline Area 1 & -- & -- & -- & -- & -- & -- & 0.0 & -- \\
\hline Area 2 & -- & -- & -- & -- & -- & -- & 0.0 & -- \\
\hline Area 3 & 0.1 & 0.0 & 0.2 & 0.1 & 0.0 & 1.7 & 2.0 & 18 \\
\hline Area 4 & -- & -- & -- & -- & -- & -- & 0.0 & -- \\
\hline Study Area & 0.1 & 0.0 & 0.2 & 0.1 & 0.0 & 1.7 & 2.0 & 18 \\
\hline \hline
\end{tabular}


Table 4.17. Sightseeing/Observation ${ }^{(a)}$ Trip Activity Duration (Hours/Trip) by River Area

\begin{tabular}{|l|c|c|c|c|c|c|c|c||}
\hline $\begin{array}{l}\text { Sightseeing/ } \\
\text { Observation }\end{array}$ & Swimming & Boating & $\begin{array}{c}\text { Water- } \\
\text { skiing }\end{array}$ & $\begin{array}{c}\text { Bank } \\
\text { Fishing }\end{array}$ & $\begin{array}{c}\text { Boat } \\
\text { Fishing }\end{array}$ & $\begin{array}{c}\text { Other } \\
\text { Activities }\end{array}$ & $\begin{array}{c}\text { Composite } \\
\text { Trip }\end{array}$ & Observations \\
\hline Area 1 & -- & -- & -- & -- & -- & -- & 0.0 & - \\
\hline Area 2 & 2.0 & 0.0 & 0.0 & 0.0 & 0.0 & 2.0 & 4.0 & 1 \\
\hline Area 3 & 0.7 & 0.2 & 0.3 & 0.0 & 0.0 & 2.1 & 3.3 & 19 \\
\hline Area 4 & -- & -- & -- & -- & -- & -- & 0.0 & -- \\
\hline Study Area & 0.8 & 0.2 & 0.3 & 0.0 & 0.0 & 2.1 & 3.3 & 20 \\
\hline (a) Includes "sightseeing", "wildlife observation", "nature study", and "spectator". \\
\hline
\end{tabular}

Table 4.18. "No Specified Activity" Trip Activity Duration (Hours/Trip) by River Area

\begin{tabular}{||c|c|c|c|c|c|c|c|c||}
\hline $\begin{array}{c}\text { No } \\
\text { Activity } \\
\text { Specified }\end{array}$ & Swimming & Boating & Waterskiing & $\begin{array}{c}\text { Bank } \\
\text { Fishing }\end{array}$ & $\begin{array}{c}\text { Boat } \\
\text { Fishing }\end{array}$ & $\begin{array}{c}\text { Other } \\
\text { Activities }\end{array}$ & $\begin{array}{c}\text { Composite } \\
\text { Trip }\end{array}$ & Observations \\
\hline Area 1 & -- & -- & -- & -- & -- & -- & 0.0 & -- \\
\hline Area 2 & 0.7 & 0.7 & 0.0 & 2.7 & 4.0 & 0.0 & 8.0 & 3 \\
\hline Area 3 & 1.4 & 0.8 & 0.8 & 0.2 & 0.1 & 0.7 & 4.0 & 51 \\
\hline Area 4 & -- & -- & -- & -- & -- & -- & 0.0 & -- \\
\hline Study Area & 1.4 & 0.8 & 0.8 & 0.3 & 0.3 & 0.7 & 4.2 & 54 \\
\hline
\end{tabular}


Table 4.19. Study Area Average Counts of Recreation Activity Participation by Weekday

\begin{tabular}{|l|l|l|l|l|l|l|l|l|l||}
\hline Weekday & $\mathbf{n}$ & $\begin{array}{c}\text { Bank } \\
\text { Fishing }\end{array}$ & $\begin{array}{c}\text { Boat } \\
\text { Fishing }\end{array}$ & Boating & Other & Swimming & Waterskiing & Windsurfing & $\begin{array}{c}\text { Average } \\
\text { Site Total }\end{array}$ \\
\hline Sunday & 24 & 1.25 & 1.38 & 24.92 & 30.38 & 18.38 & 9.88 & 0.04 & 86.21 \\
\hline Monday & 84 & 0.14 & 0.52 & 2.94 & 6.06 & 2.02 & 0.80 & 0.00 & 12.49 \\
\hline Tuesday & 67 & 0.42 & 0.24 & 3.61 & 7.39 & 2.49 & 1.09 & 0.00 & 15.24 \\
\hline Wednesday & 48 & 0.48 & 0.33 & 4.40 & 5.71 & 1.35 & 2.23 & 0.02 & 14.52 \\
\hline Thursday & 67 & 0.57 & 0.67 & 4.54 & 10.61 & 5.79 & 2.99 & 0.00 & 25.16 \\
\hline Friday & 55 & 0.35 & 0.64 & 9.60 & 8.65 & 3.22 & 4.13 & 0.04 & 26.62 \\
\hline Saturday & 52 & 0.46 & 0.71 & 9.94 & 28.83 & 3.90 & 4.96 & 0.00 & 48.81 \\
\hline Totals ${ }^{(a)}$ & 397 & 0.44 & 0.57 & 6.67 & 11.82 & 4.06 & 2.94 & 0.01 & 26.51 \\
\hline
\end{tabular}

(a) The specific location was not recorded for one observation, but the observation was valid in all other respects and included in the study area total.

Table 4.20. Average Counts of Recreation Activity Participation by Weekday in Area 1

\begin{tabular}{||l|c|c|c|c|c|c|c|c|c||}
\hline Weekday & $\mathbf{n}$ & $\begin{array}{c}\text { Bank } \\
\text { Fishing }\end{array}$ & $\begin{array}{c}\text { Boat } \\
\text { Fishing }\end{array}$ & Boating & Other & Swimming & Waterskiing & Windsurfing & $\begin{array}{c}\text { Average } \\
\text { Site Total }\end{array}$ \\
\hline Sunday & 3 & 2.67 & 0.33 & 1.00 & 0.00 & 0.00 & 0.00 & 0.00 & 4.00 \\
\hline Monday & 2 & 0.00 & 0.00 & 0.00 & 1.50 & 0.00 & 0.00 & 0.00 & 1.50 \\
\hline Tuesday & 5 & 0.00 & 0.00 & 0.00 & 2.00 & 0.20 & 0.00 & 0.00 & 2.20 \\
\hline Wednesday & 8 & 0.25 & 0.00 & 0.75 & 0.63 & 0.13 & 0.00 & 0.00 & 1.75 \\
\hline Thursday & 4 & 0.00 & 0.75 & 0.50 & 0.50 & 0.00 & 0.00 & 0.00 & 1.75 \\
\hline Friday & 1 & 0.00 & 0.00 & 0.00 & 0.00 & 0.00 & 0.00 & 0.00 & 0.00 \\
\hline Saturday & 4 & 0.00 & 0.00 & 0.00 & 1.00 & 1.50 & 0.00 & 0.00 & 2.50 \\
\hline Totals & 27 & 0.37 & 0.15 & 0.41 & 0.89 & 0.30 & 0.00 & 0.00 & 2.11 \\
\hline \hline
\end{tabular}


Table 4.21. Average Counts of Recreation Activity Participation by Weekday in Area 2

\begin{tabular}{|l|c|c|c|c|c|c|c|c|c||}
\hline Weekday & $\mathbf{n}$ & $\begin{array}{c}\text { Bank } \\
\text { Fishing }\end{array}$ & $\begin{array}{c}\text { Boat } \\
\text { Fishing }\end{array}$ & Boating & Other & Swimming & Waterskiing & Windsurfing & $\begin{array}{c}\text { Average } \\
\text { Site } \\
\text { Total }\end{array}$ \\
\hline Sunday & 3 & 0.00 & 0.00 & 4.33 & 2.00 & 2.67 & 0.33 & 0.00 & 9.33 \\
\hline Monday & 5 & 0.00 & 2.20 & 0.00 & 3.00 & 0.00 & 0.00 & 0.00 & 5.20 \\
\hline Tuesday & 4 & 0.00 & 1.00 & 6.00 & 1.00 & 0.00 & 0.00 & 0.00 & 8.00 \\
\hline Wednesday & 10 & 0.60 & 1.40 & 0.00 & 0.90 & 0.00 & 0.00 & 0.00 & 2.90 \\
\hline Thursday & 4 & 0.50 & 3.50 & 2.50 & 0.25 & 0.00 & 0.00 & 0.00 & 6.75 \\
\hline Friday & 3 & 0.00 & 0.00 & 0.00 & 2.33 & 0.00 & 0.00 & 0.00 & 2.33 \\
\hline Saturday & 3 & 0.33 & 3.67 & 2.33 & 1.00 & 0.00 & 0.00 & 0.00 & 7.33 \\
\hline Totals & 32 & 0.28 & 1.69 & 1.69 & 1.41 & 0.25 & 0.03 & 0.00 & 5.34 \\
\hline
\end{tabular}

Table 4.22. Average Counts of Recreation Activity Participation by Weekday in Area 3

\begin{tabular}{||l|c|c|c|c|c|c|c|c|c||}
\hline Weekday & $\mathbf{n}$ & $\begin{array}{c}\text { Fank } \\
\text { Fishing }\end{array}$ & $\begin{array}{c}\text { Boat } \\
\text { Fishing }\end{array}$ & Boating & Other & Swimming & Waterskiing & Windsurfing & $\begin{array}{c}\text { Average } \\
\text { Site } \\
\text { Total }\end{array}$ \\
\hline Sunday & 18 & 1.22 & 1.78 & 32.33 & 40.17 & 24.06 & 13.11 & 0.06 & 112.72 \\
\hline Monday & 76 & 0.16 & 0.43 & 3.25 & 6.42 & 2.24 & 0.83 & 0.00 & 13.33 \\
\hline Tuesday & 58 & 0.48 & 0.21 & 3.76 & 8.29 & 2.86 & 1.26 & 0.00 & 16.86 \\
\hline Wednesday & 30 & 0.50 & 0.07 & 6.83 & 8.67 & 2.13 & 3.57 & 0.03 & 21.80 \\
\hline Thursday & 59 & 0.61 & 0.47 & 4.95 & 12.00 & 6.58 & 3.39 & 0.00 & 28.00 \\
\hline Friday & 51 & 0.37 & 0.69 & 10.35 & 9.20 & 3.47 & 4.45 & 0.04 & 28.57 \\
\hline Saturday & 45 & 0.51 & 0.58 & 11.33 & 33.16 & 4.38 & 5.73 & 0.00 & 55.69 \\
\hline Totals & 337 & 0.46 & 0.50 & 7.66 & 13.71 & 4.73 & 3.45 & 0.01 & 30.53 \\
\hline
\end{tabular}

Table 4.23. Proportion of Trip Time by River Area

\begin{tabular}{|c|c|c|c|c|c|c|c|c|}
\hline \multirow{2}{*}{$\begin{array}{c}\text { Time } \\
(\%)\end{array}$} & \multicolumn{4}{|c|}{ Count } & \multirow{2}{*}{$\begin{array}{c}\text { Area } 1 \\
(\%)\end{array}$} & \multirow{2}{*}{$\begin{array}{c}\text { Area } 2 \\
(\%)\end{array}$} & \multirow{2}{*}{$\begin{array}{c}\text { Area } 3 \\
(\%)\end{array}$} & \multirow{2}{*}{$\begin{array}{c}\text { Area } 4 \\
(\%)\end{array}$} \\
\hline & Area 1 & Area 2 & Area 3 & Area 4 & & & & \\
\hline 25 & 1 & 4 & 1 & 0 & 20.0 & 25.0 & 0.4 & 0.0 \\
\hline 50 & 1 & 3 & 7 & 3 & 20.0 & 18.8 & 2.9 & 50.0 \\
\hline 75 & 0 & 1 & 2 & 0 & 0.0 & 6.3 & 0.8 & 0.0 \\
\hline 100 & 3 & 8 & 229 & 3 & 60.0 & 50.0 & 95.8 & 50.0 \\
\hline Total & 5 & 1 & 239 & 6 & 75.0 & 69.4 & 97.9 & 75.0 \\
\hline
\end{tabular}


Table 4.24. Target Species of Fishing Parties

\begin{tabular}{|c|c|c|c|c|c|}
\hline Fish & $\begin{array}{c}\text { Parties } \\
\text { (n) }\end{array}$ & People & $\begin{array}{c}\text { Parties } \\
(\%)\end{array}$ & $\begin{array}{l}\text { SD } \\
(\%)\end{array}$ & $\begin{array}{c}\text { People } \\
(\%)\end{array}$ \\
\hline Salmonid & 6 & 16 & 19.4 & 40.2 & 16.0 \\
\hline Northern Pikeminnow & 7 & 16 & 22.6 & 42.5 & 16.0 \\
\hline Bass & 8 & 18 & 25.8 & 44.5 & 18.0 \\
\hline Sturgeon & 1 & 2 & 3.2 & 18.0 & 2.0 \\
\hline Walleye & 2 & 4 & 6.5 & 25.0 & 4.0 \\
\hline Anything & 11 & 51 & 35.5 & 48.6 & 51.0 \\
\hline Catfish & 2 & 5 & 6.5 & 25.0 & 5.0 \\
\hline Totals $^{(\mathrm{a})}$ & 31 & 100 & 12.1 & 32.7 & 7.8 \\
\hline
\end{tabular}

(a) Parties could report more than one species sought.

Table 4.25. Total and Local Portion Trip Expenditure Profile for Entire Sample ( $n=219$ parties)

\begin{tabular}{||l|c|c|c|c|c||}
\hline \multicolumn{1}{|c|}{ Expenditure Category } & $\begin{array}{c}\text { Entire } \\
\text { Trip } \\
\text { Expense } \\
\mathbf{\$} / \text { Party) }\end{array}$ & $\begin{array}{c}\text { Benton/ } \\
\text { Franklin } \\
\text { County } \\
\mathbf{\$} / \text { Party })\end{array}$ & $\begin{array}{c}\text { Entire } \\
\text { Trip } \\
\text { Expense } \\
\mathbf{\$} / \text { Person) }\end{array}$ & $\begin{array}{c}\text { Fenton/ } \\
\text { Franklin } \\
\text { County } \\
\mathbf{\$} / \text { Person) }\end{array}$ & $\begin{array}{c}\text { Percent } \\
\text { Spent in } \\
\text { Benton/ } \\
\text { Franklin } \\
(\%)\end{array}$ \\
\hline Restaurants/taverns & 6.03 & 5.04 & 1.38 & 1.16 & 83.7 \\
\hline Lodging/camping & 6.26 & 4.58 & 1.44 & 1.05 & 73.2 \\
\hline Equipment (fishing gear, supplies, etc.) & 2.20 & 2.20 & 0.50 & 0.50 & 100.0 \\
\hline Grocery, supplies, etc, for this trip & 36.00 & 15.40 & 8.27 & 3.54 & 42.8 \\
\hline Licenses, permits & 2.14 & 1.49 & 0.49 & 0.34 & 69.5 \\
\hline Bait/tackle & 4.76 & 1.04 & 1.09 & 0.24 & 21.8 \\
\hline Gasoline/oil - boat/jet ski & 10.62 & 7.83 & 2.44 & 1.80 & 73.8 \\
\hline Gasoline/oil for vehicle & 12.06 & 7.92 & 2.77 & 1.82 & 65.7 \\
\hline Other ( repairs, swim trunks, etc)) & 11.56 & 2.28 & 2.66 & 0.52 & 19.7 \\
\hline Total Itemized Expenditures & 91.62 & 47.77 & 21.03 & 10.97 & 52.1 \\
\hline Unitemized Expenditures & 48.19 & 30.89 & 11.06 & 7.09 & 64.1 \\
\hline Total Average Trip Expenditures & 139.81 & 78.67 & 32.10 & 18.06 & 56.3 \\
\hline \hline
\end{tabular}


Table 4.26. River-Based Recreation Trip Expenditures (Dollars) by Party by Activity (page 1 of 2)

\begin{tabular}{|c|c|c|c|c|c|c|c|c|c|c|c|c|c|c|c|}
\hline \multirow[b]{2}{*}{$\begin{array}{l}\text { Expenditure } \\
\text { Category }\end{array}$} & \multicolumn{3}{|c|}{ Boating/Sailing } & \multicolumn{3}{|c|}{ Fishing [Boat or Bank] } & \multicolumn{3}{|c|}{ Hiking/Walking } & \multicolumn{3}{|c|}{ Swimming/Wading } & \multicolumn{3}{|c|}{ Water-skiing/Jetskiing } \\
\hline & $\begin{array}{c}\text { Total } \\
(n=32)\end{array}$ & $\begin{array}{l}\text { Benton/ } \\
\text { Franklin }\end{array}$ & $\begin{array}{c}\% \\
\text { Local }\end{array}$ & $\begin{array}{c}\text { Total } \\
(\mathbf{n}=21)\end{array}$ & $\begin{array}{l}\text { Benton/ } \\
\text { Franklin }\end{array}$ & $\begin{array}{c}\% \\
\text { Local }\end{array}$ & $\begin{array}{c}\text { Total } \\
(\mathbf{n}=12)\end{array}$ & $\begin{array}{c}\text { Benton/ } \\
\text { Franklin }\end{array}$ & $\begin{array}{c}\% \\
\text { Local }\end{array}$ & $\begin{array}{c}\text { Total } \\
(\mathbf{n}=26)\end{array}$ & \begin{tabular}{|c|} 
Benton/ \\
Franklin
\end{tabular} & $\begin{array}{c}\% \\
\text { Local }\end{array}$ & $\begin{array}{l}\text { Total } \\
(\mathbf{n}=25)\end{array}$ & $\begin{array}{l}\text { Benton/ } \\
\text { Franklin }\end{array}$ & $\begin{array}{c}\% \\
\text { Local }\end{array}$ \\
\hline Restaurants/taverns & 2.81 & 2.81 & 100.0 & 0.95 & 0.95 & 100.0 & 49.58 & 37.92 & 76.5 & 1.15 & 1.15 & 100.0 & 25.20 & 17.20 & 68.3 \\
\hline Lodging/camping & 1.56 & 1.56 & 100.0 & 0.00 & 0.00 & 0.0 & 25.00 & 25.00 & 0.0 & 0.00 & 0.00 & 0.0 & 28.40 & 12.40 & 43.7 \\
\hline $\begin{array}{l}\text { Equipment (fishing } \\
\text { gear, supplies, etc.) }\end{array}$ & 2.34 & 2.34 & 100.0 & 0.00 & 0.00 & 0.0 & 0.00 & 0.00 & 0.0 & 9.62 & 9.62 & 100.0 & 8.00 & 8.00 & 100.0 \\
\hline $\begin{array}{l}\text { Grocery, supplies, } \\
\text { etc, for this trip }\end{array}$ & 43.88 & 34.91 & 79.6 & 13.57 & 11.43 & 84.2 & 10.67 & 10.67 & 100.0 & 12.88 & 11.92 & 92.5 & 41.08 & 26.68 & 64.9 \\
\hline Licenses, permits & 3.97 & 2.34 & $58.9 \%$ & 17.05 & 12.10 & 71.0 & 0.00 & 0.00 & 0.0 & 0.00 & 0.00 & 0.0 & 0.00 & 0.00 & 0.0 \\
\hline Bait/tackle & 0.47 & 0.00 & 0.0 & 40.86 & 2.29 & 5.6 & 0.00 & 0.00 & 0.0 & 0.00 & 0.00 & 0.0 & 8.00 & 8.00 & 100.0 \\
\hline $\begin{array}{l}\text { Gasoline/oil - } \\
\text { boat/jet ski }\end{array}$ & 30.63 & 21.47 & 70.1 & 9.95 & 9.00 & 90.5 & 0.00 & 0.00 & 0.0 & 5.00 & 5.00 & 100.0 & 28.04 & 27.24 & 97.1 \\
\hline $\begin{array}{l}\text { Gasoline/oil for } \\
\text { vehicle }\end{array}$ & 12.53 & 11.38 & 90.8 & 13.00 & 9.10 & 70.0 & 11.58 & 7.42 & 64.1 & 3.04 & 2.58 & 84.9 & 50.16 & 34.36 & 68.5 \\
\hline $\begin{array}{l}\text { Other ( repairs, } \\
\text { swim trunks, etc) }\end{array}$ & 63.75 & 0.63 & 1.0 & 9.52 & 0.00 & 0.0 & 0.42 & 0.42 & 100.0 & 2.12 & 2.12 & 100.0 & 1.40 & 1.40 & 100.0 \\
\hline $\begin{array}{l}\text { Total Itemized } \\
\text { Expenditures }\end{array}$ & 161.94 & 77.44 & 47.8 & 104.90 & 44.87 & 42.8 & 97.25 & 81.43 & 83.7 & 33.81 & 32.39 & 95.8 & 190.28 & 135.28 & 71.1 \\
\hline $\begin{array}{l}\text { Unitemized } \\
\text { Expenditures }\end{array}$ & 150.16 & 56.41 & 37.6 & 202.00 & 201.05 & 99.5 & 0.33 & 0.33 & 100.0 & 4.31 & 4.31 & 100.0 & 1.60 & 1.60 & 100.0 \\
\hline $\begin{array}{l}\text { Total Average Trip } \\
\text { Expenditures }\end{array}$ & 312.10 & 133.85 & 42.9 & 306.90 & 245.92 & 80.1 & 97.58 & 81.76 & 83.8 & 38.12 & 36.70 & 96.3 & 191.88 & 136.88 & 71.3 \\
\hline
\end{tabular}


Table 4.26. (contd) (page 2 of 2)

\begin{tabular}{|c|c|c|c|c|c|c|c|c|c|c|c|c|}
\hline \multirow[b]{2}{*}{ Expenditure Category } & \multicolumn{3}{|c|}{ Boat Race/Water Follies } & \multicolumn{3}{|c|}{ Picnicking } & \multicolumn{3}{|c|}{ Sightseeing Related } & \multicolumn{3}{|c|}{ Other Activities } \\
\hline & $\begin{array}{l}\text { Total } \\
(\mathrm{n}=6)\end{array}$ & $\begin{array}{l}\text { Benton/ } \\
\text { Franklin }\end{array}$ & $\begin{array}{c}\% \\
\text { Local }\end{array}$ & $\begin{array}{l}\text { Total } \\
(\mathrm{n}=40)\end{array}$ & $\begin{array}{l}\text { Benton/ } \\
\text { Franklin }\end{array}$ & $\%$ Local & $\begin{array}{l}\text { Total } \\
(n=12)\end{array}$ & $\begin{array}{l}\text { Benton/ } \\
\text { Franklin }\end{array}$ & $\begin{array}{c}\% \\
\text { Local }\end{array}$ & $\begin{array}{c}\text { Total } \\
(n=45)\end{array}$ & $\begin{array}{l}\text { Benton/ } \\
\text { Franklin }\end{array}$ & $\begin{array}{c}\% \\
\text { Local }\end{array}$ \\
\hline Restaurants/taverns & 45.00 & 5.00 & 11.1 & 4.00 & 1.38 & 34.5 & 2.08 & 1.67 & 80.3 & 1.67 & 1.67 & 100.0 \\
\hline Lodging/camping & 18.33 & 18.33 & 100.0 & 6.25 & 6.25 & 100.0 & 6.25 & 6.25 & 100.0 & 0.00 & 0.00 & 0.0 \\
\hline $\begin{array}{l}\text { Equipment (fishing gear, } \\
\text { supplies, etc.) }\end{array}$ & 0.00 & 0.00 & 0.0 & 0.00 & 0.00 & 0.0 & 0.00 & 0.00 & 0.0 & 0.00 & 0.00 & 0.0 \\
\hline $\begin{array}{l}\text { Grocery, supplies, etc, for } \\
\text { this trip }\end{array}$ & 160.83 & 81.67 & 50.8 & 98.15 & 10.60 & 10.8 & 2.08 & 2.08 & 100.0 & 11.31 & 6.20 & 54.8 \\
\hline Licenses, permits & 0.00 & 0.00 & 0.0 & 0.65 & 0.65 & 100.0 & 0.00 & 0.00 & 0.0 & 0.00 & 0.00 & 0.0 \\
\hline Bait/tackle & 3.67 & 0.00 & 0.0 & 1.05 & 0.00 & 0.0 & 0.00 & 0.00 & 0.0 & 0.00 & 0.00 & 0.0 \\
\hline Gasoline/oil - boat/jet ski & 5.00 & 1.67 & 33.4 & 4.63 & 0.50 & 10.8 & 0.42 & 0.42 & 100.0 & 6.60 & 3.33 & 50.5 \\
\hline Gasoline/oil for vehicle & 42.00 & 12.83 & 30.5 & 4.63 & 1.43 & 30.9 & 6.08 & 3.83 & 63.0 & 5.02 & 3.13 & 62.4 \\
\hline $\begin{array}{l}\text { Other ( repairs, swim } \\
\text { trunks, etc) }\end{array}$ & 16.67 & 16.67 & 100.0 & 0.23 & 0.23 & 100.0 & 25.00 & 25.00 & 100.0 & 0.44 & 0.44 & 100.0 \\
\hline $\begin{array}{l}\text { Total Itemized } \\
\text { Expenditures }\end{array}$ & 291.50 & 136.17 & 46.7 & 119.59 & 21.04 & 17.6 & 41.91 & 39.25 & 93.7 & 25.04 & 14.77 & 59.0 \\
\hline Unitemized Expenditures & 83.33 & 66.67 & 80.0 & 21.63 & 12.00 & 55.5 & 1.25 & 1.25 & 100.0 & 20.78 & 6.78 & 32.6 \\
\hline $\begin{array}{l}\text { Total Average Trip } \\
\text { Expenditures }\end{array}$ & 374.83 & 202.84 & 54.1 & 141.22 & 33.04 & 23.4 & 43.16 & 40.50 & 93.8 & 45.82 & 21.55 & 47.0 \\
\hline
\end{tabular}


Table 4.27. River-Based Recreation Trip Expenditures (Dollars) by Party by Point of Origin

\begin{tabular}{|c|c|c|c|c|c|c|c|c|c|c|c|c|c|c|c|}
\hline \multirow[b]{2}{*}{$\begin{array}{c}\text { Expenditure } \\
\text { Category }\end{array}$} & \multicolumn{3}{|c|}{ Study Area } & \multicolumn{3}{|c|}{ Eastern Washington } & \multicolumn{3}{|c|}{ "Western Washington } & \multicolumn{3}{|c|}{ Oregon } & \multicolumn{3}{|c|}{ Other Areas } \\
\hline & $\begin{array}{c}\text { Total } \\
(\mathrm{n}=172)\end{array}$ & $\begin{array}{c}\text { Benton/ } \\
\text { Franklin }\end{array}$ & $\begin{array}{c}\% \\
\text { Local }\end{array}$ & $\begin{array}{c}\text { Total } \\
(\mathrm{n}=19)\end{array}$ & $\begin{array}{c}\text { Benton/ } \\
\text { Franklin }\end{array}$ & $\begin{array}{c}\% \\
\text { Local }\end{array}$ & $\begin{array}{c}\text { Total } \\
(n=14)\end{array}$ & \begin{tabular}{|c|} 
Benton/ \\
Franklin
\end{tabular} & $\begin{array}{c}\% \\
\text { Local }\end{array}$ & $\begin{array}{l}\text { Total } \\
(\mathrm{n}=3)\end{array}$ & \begin{tabular}{|c|} 
Benton/ \\
Franklin
\end{tabular} & $\begin{array}{c}\% \\
\text { Local }\end{array}$ & $\begin{array}{c}\text { Total } \\
(\mathrm{n}=11)\end{array}$ & $\begin{array}{c}\text { Benton/ } \\
\text { Franklin }\end{array}$ & $\begin{array}{c}\% \\
\text { Local }\end{array}$ \\
\hline \begin{tabular}{|l} 
Restaurants/ \\
taverns
\end{tabular} & 5.15 & 3.17 & 61.6 & 6.32 & 6.32 & 100.0 & 32.14 & 15.00 & 46.7 & 33.33 & 33.33 & 100.0 & 39.09 & 20.91 & 53.5 \\
\hline \begin{tabular}{|l} 
Lodging/ \\
camping
\end{tabular} & 0.29 & 0.29 & 100.0 & 0.00 & 0.00 & 0.0 & 16.79 & 16.79 & 100.0 & 110.00 & 110.00 & 100.0 & 80.00 & 43.64 & 54.5 \\
\hline $\begin{array}{l}\text { Equipment } \\
\text { (fishing gear, } \\
\text { supplies, etc.) }\end{array}$ & 1.89 & 1.89 & 100.0 & 0.00 & 0.00 & 0.0 & 14.29 & 14.29 & 100.0 & 0.00 & 0.00 & 0.0 & 0.00 & 0.00 & 0.0 \\
\hline $\begin{array}{l}\text { Grocery, supplies, } \\
\text { etc, for this trip }\end{array}$ & 35.44 & 12.83 & 36.2 & 18.95 & 15.26 & 80.6 & 114.64 & 62.86 & 54.8 & 83.33 & 83.33 & 100.0 & 26.64 & 4.82 & 18.1 \\
\hline Licenses, permits & 2.84 & 1.94 & 68.1 & 0.00 & 0.00 & 0.0 & 1.57 & 1.57 & 100.0 & 0.00 & 0.00 & 0.0 & 0.00 & 0.00 & 0.0 \\
\hline Bait/tackle & 6.08 & 1.27 & 20.9 & 2.11 & 0.00 & 0.0 & 3.71 & 2.14 & 57.7 & 0.00 & 0.00 & 0.0 & 0.00 & 0.00 & 0.0 \\
\hline \begin{tabular}{|l} 
Gasoline/oil - \\
boat/jet ski
\end{tabular} & 11.42 & 7.90 & 69.2 & 7.37 & 6.84 & 92.9 & 19.14 & 17.00 & 88.8 & 10.00 & 10.00 & 100.0 & 12.27 & 10.45 & 85.2 \\
\hline $\begin{array}{l}\text { Gasoline/oil for } \\
\text { vehicle }\end{array}$ & 4.78 & 3.84 & 80.3 & 10.74 & 4.47 & 41.7 & 57.50 & 37.86 & 65.8 & 146.67 & 136.67 & 93.2 & 55.64 & 18.82 & 33.8 \\
\hline $\begin{array}{l}\text { Other ( repairs, } \\
\text { swim trunks, etc) }\end{array}$ & 14.09 & 1.19 & 8.4 & 0.26 & 0.26 & 100.0 & 23.93 & 23.93 & 100.0 & 0.00 & 0.00 & 0.0 & 0.00 & 0.00 & 0.0 \\
\hline \begin{tabular}{|l|l|} 
Total Itemized \\
Expenditures
\end{tabular} & 81.98 & 34.31 & 41.9 & 45.74 & 33.16 & 72.5 & 283.71 & 191.43 & 67.5 & 383.33 & 373.33 & 97.4 & 213.64 & 98.64 & 46.2 \\
\hline \begin{tabular}{|l} 
Unitemized \\
Expenditures
\end{tabular} & 33.77 & 14.41 & 42.7 & 30.00 & 24.47 & 81.6 & 1.07 & 1.07 & 100.0 & 0.00 & 0.00 & 0.0 & 465.91 & 402.27 & 86.3 \\
\hline \begin{tabular}{|l|} 
Total Average \\
Trip Expenditures
\end{tabular} & 115.74 & 48.72 & 42.1 & 75.74 & 57.63 & 76.1 & 284.79 & 192.50 & 67.6 & 383.33 & 373.33 & 97.4 & 679.55 & 500.91 & 73.7 \\
\hline
\end{tabular}


Table 4.28. River-Based Recreation Trip Expenditures (Dollars) by Party by River Area

\begin{tabular}{|c|c|c|c|c|c|c|c|c|c|}
\hline \multirow[b]{2}{*}{ Expenditure Category } & \multicolumn{3}{|c|}{ Area 1} & \multicolumn{3}{|c|}{ Area 2} & \multicolumn{3}{|c|}{ Area 3} \\
\hline & $\begin{array}{l}\text { Total } \\
(n=3)\end{array}$ & $\begin{array}{l}\text { Benton/ } \\
\text { Franklin }\end{array}$ & $\begin{array}{c}\text { Local } \\
(\%)\end{array}$ & $\begin{array}{l}\text { Total } \\
(n=7)\end{array}$ & $\begin{array}{c}\text { Benton/ } \\
\text { Franklin }\end{array}$ & $\begin{array}{c}\text { Local } \\
(\%)\end{array}$ & $\begin{array}{c}\text { Total } \\
(n=209)\end{array}$ & $\begin{array}{l}\text { Benton/ } \\
\text { Franklin }\end{array}$ & $\begin{array}{c}\text { Local } \\
(\%)\end{array}$ \\
\hline Restaurants/Taverns & 0.00 & 0.00 & 0.0 & 2.86 & 2.86 & 100.0 & 6.79 & 5.67 & 83.5 \\
\hline Lodging/Camping & 0.00 & 0.00 & 0.0 & 0.00 & 0.00 & 0.0 & 7.15 & 5.24 & 73.2 \\
\hline Equipment (Fishing Gear, Supplies, Etc.) & 0.00 & 0.00 & 0.0 & 0.00 & 0.00 & 0.0 & 2.51 & 2.51 & 100.0 \\
\hline Grocery, Supplies, Etc, for This Trip & 0.00 & 0.00 & 0.0 & 6.43 & 2.86 & 44.4 & 40.95 & 17.51 & 42.8 \\
\hline Licenses, Permits & 0.00 & 0.00 & 0.0 & 0.00 & 0.00 & 0.0 & 0.00 & 0.00 & 0.0 \\
\hline Bait/Tackle & 0.00 & 0.00 & 0.0 & 2.86 & 2.86 & 100.0 & 2.35 & 1.60 & 68.2 \\
\hline Gasoline/Oil - Boat/Jet Ski & 13.33 & 0.00 & 0.0 & 0.00 & 0.00 & 0.0 & 5.25 & 1.19 & 22.6 \\
\hline Gasoline/Oil For Vehicle & 0.00 & 0.00 & 0.0 & 12.14 & 10.71 & 88.2 & 11.73 & 8.60 & 73.3 \\
\hline Other ( Repairs, Swim Trunks, Etc) & 7.00 & 1.67 & 23.8 & 7.00 & 0.57 & 8.2 & 13.46 & 9.01 & 66.9 \\
\hline Total Itemized Expenditures & 20.33 & 1.67 & 8.2 & 31.29 & 19.86 & 63.5 & 90.20 & 51.33 & 56.9 \\
\hline Unitemized Expenditures & 6.67 & 0.00 & 0.0 & 674.29 & 588.57 & 87.3 & 32.43 & 15.61 & 48.1 \\
\hline Total Average Trip Expenditures & 27.00 & 1.67 & 6.2 & 705.57 & 608.43 & 86.2 & 122.63 & 66.94 & 54.6 \\
\hline
\end{tabular}




\subsection{Discussion}

Results reported here provide a valuable baseline assessment of the current summer recreation situation in the Columbia River study area. This section highlights any surprising or counterintuitive results deriving from the study. It also indicates the known issues affecting the reliability of these results for use in baselining the SAC modeling exercise.

The survey, complemented by field observations, successfully accomplished the objectives outlined with some caveats. The study provides a thorough description of summer river recreation participation, activities, trip characteristics and duration, and trip expenditures. If a goal of the SAC approach is to model based on a complete picture of river recreation on the Columbia, an obvious limitation of this study is the focus on the summer season. This region of the Columbia Basin is well known for salmon fishing and waterfowl hunting. Primary data about these river-based activities could not be collected because these activities occur principally in the Spring and Fall.

As becomes apparent from statistical results, the uncertainty bands tend to be quite wide for most survey means reported. Small sample sizes lead to these results in most cases. However, the survey, in concert with the field observations, documents the variability of recreation participation on the Columbia. Considering the tremendous range in valid responses about trip duration, trip activities, days per year spent in river recreation, and trip expenditures discovered in this study, much larger sample sizes are recommended in future data collection efforts. In the case of wide ranging valid responses, significantly increasing sample sizes is the most effective way to tighten uncertainty bands needed for SAC modeling efforts. Uncertainty in the responses could also be mitigated to some lesser degree by using follow-up questions to probe for valid responses. That approach is more conducive to a mail survey data collection method.

A surprising result relates to the local/non-local split in trip expenditures reported by parties originating from within the study area. Local visitors report that just over 42 percent of their trip expenses were incurred in the Benton/Franklin County local area. Those starting their trip from outside the study area show a significantly higher proportion of local expenditure than local visitors. In actuality, we would expect to see the reverse or a much closer spread of local proportions. There is no adequate explanation for this result. However, it is possible the number of observations by visitors from outside the study area was low enough that a few major expenditures made locally (buying a boat, motor, or major repairs) are skewing the local expenditure volume. Such a situation leads to an overly high local proportion of trip expense for this group. Some parties did report spending several hundreds to thousands of dollars locally on the trip.

Trip length-of-stay for non-local visitors were affected by a significant proportion of long-term or "destination" river enthusiasts. This segment, representing over 10 percent of the non-local survey observations, typically spends 10-14 days on a single trip to the Columbia River study area, and some spend the whole summer. As a group, they are boaters that either fish or water ski. 
Results from eliciting the fish species sought by those fishing further indicate the primary population of anglers fell outside this survey sample. Summer fishing would seem to be more of a by-product activity engaged in as a part of some other primary activity. This is less true in Areas 1 and 2, where fishing typically is the greatest proportion of a composite trip.

From analysis of the final set of survey questions - relating to alternative choices of recreation site or recreation activity - there is some indication of misunderstanding the frame of reference. From the freeform responses, a significant proportion of those surveyed interpreted the question as an indication that some form of governmental intervention in the recreational use of the river was under consideration. Judging from the responses, this false impression could have been generated either by interviewer framing of the question or by preconceived notions on the part of respondents. No conclusive indication was observed either way.

The detailed results reported for trip expenditures can be used from this point to determine the composition of river recreation-related final demand for goods and services. The local/non-local components of the expenditure profiles inform the economic model about what leakage from the local economy can be expected as a result of river-recreation-generated final demand. Having estimates of the recreation-derived final demand and the associated economic leakage from the region permits the estimation of the current economic effects in the local economy.

Economic impact estimation measures the effect of changes in final demand caused by some new injection of demand into the local economy, or by the elimination of some portion of existing demand in the local economy. To reliably estimate economic impacts for scenarios involving river recreation, information about recreation site and recreation activity substitution is required. To the degree that a scenario would cause recreationists to leave the area to pursue the same activity at a non-local site, an economic impact would be generated if that change resulted in expenditures leaving the local economy. By the same logic, any net change in local river recreation expenditures caused by switching to other nonriver-based activities also would cause an economic impact.

The survey attempted to elicit these substitution preferences from the respondents. However, because this portion of the survey resulted in significant nonresponse and potential bias from question framing, follow-up is recommended. Another type of instrument might permit better or more reliable inferences about potential or hypothetical substitution behavior in the case of river recreation. 


\subsection{References}

Defense Nuclear Facilities Safety Board (DNFSB). 1994. Recommendation 94-2. Letter from J.T. Conway to H.R. O’Leary Reguarding Low-Level Waste Management, September 8, 1994. Accession No. 15481. http://www.dnfsb.gov/pub_docs/dnfsb/ar_1995.html

Kincaid, C.T., P.W. Eslinger, W.E. Nichols, A.L. Bunn, R.W. Bryce, T.B. Miley, M.C. Richmond, S.F. Snyder, and R.L. Aaberg. 2000. Groundwater/Vadose Zone Integration Project, System Assessment Capability (Revision 0), Assessment Description, Requirements, Software Design, and Test Plan. BHI-01365. Bechtel Hanford Inc., Richland, Washington. http://www.bhierc.com/projects/vadose/docs/pubrev/bhi01365.pdf

U.S. Army Corps of Engineers (USACE). 2001. Natural Resource Management System Historical Data. U.S. Army Corps of Engineers, Waterways Experiment Station, Vicksburg, Massachusetts. http://corpslakes.usace.army.mil/employees/nrms/nrms.html

U.S. Department of Energy (DOE-RL). 1998. Screening Assessment and Requirements for a Comprehensive Assessment: Columbia River Comprehensive Impact Assessment. DOE/RL-96-16. U.S. Department of Energy, Richland Operations Office, Richland, Washington. http://sesp.pn.gov/reports/crcia/reports.htm

Washington Department of Fish and Wildlife (WDFW). 2002. Fall/Winter 2001-2002 Yakima River/Hanford Reach Salmon Reports and Ringold Steelhead Reports. Washington Department of Fish ans Wildlife, South Central Washington Region 3 Office, Yakima, Washington.

http://www.wa.gov/wdfw/fish/creel/reg3/ 